\title{
Pore-water chemistry in mangrove sediments: relationship with species composition and developmental stages (French Guiana)
}

\author{
C. Marchand ạ, F. Baltzer $\underline{b}, \mathrm{E}$. Lallier-Vergèsa and P. Albérica
}

a Institut des Sciences de la Terre d'Orléans, UMR 6113 C NRS-UO, Université d'Orléans, G éosciences, 45067, Orléans, France

b Département des Sc iences de la Terre, Orsayterre FRE 2566 CNRS, Université Paris Sud, 91405, Orsa y cedex, France

\section{Abstract}

Spatial and seasonal variability of sedimentary salinity, $\mathrm{pH}$, redox potential and solid phase sulphide concentration were investigated in a range of mangrove communities along the coast of French Guiana. Seasonal depth distributions of these parameters and organic content were compared within Avicennia, Rhizophora and mixed mangrove stands at different stages of plant development. Mangrove communities and variable surface water inputs strongly impact sediment and ground water properties. In the upper sediment, changes in salinity are mainly controlled by seasonal conditions, transpiration and proximity of fresh water influx, whereas we suggest that constant basal salinity results from an accumulation of salt that has migrated as a result of density driven convection processes. There are no clear differences between the depth distributions of salinity obtained beneath Avicennia geminans and Rhizophora mangle stands, implying that plant zonations are not primarily controlled by soil salinity in this environment. Nevertheless, R. mangle grows in places subjected to the greatest variability in freshwater influxes, suggesting that Rhizophora might require or withstand occasional inundation by fresh water. Beneath Rhizophora stands, sediment properties reflect anaerobic and sulphidic conditions close to the sediment surface. In contrast, beneath Avic ennia stands, sediment geochemistry mostly depends on the stages in forest development, on contents in sedimentary organic matter and on seasonal changes. In the early stage of Avicennia settlement, the sediment at the level of radial, pneumatophore-bearing cable roots, displays permanent suboxic conditions with Eh values reaching $400 \mathrm{mV}$. These high Ehs are interpreted as an effect of the oxidation produced by the cable root system. The development of mature Avic ennia stands results in accumulation of sedimentary organic matter and promotes low Ehs and the reduction of pore-water sulphate. Near cable root level, the oxidation process observed in pioneer mangroves results in a reoxidation of solid sulphides produced previously. During dry conditions, the desiccation of the upper sediment adds its oxidation effects to those of root activity. As a result, suboxic processes dominate in the upper, 20-cm-thick layer; organic matter decomposition and sulphur oxidation strongly acidify the sediment. Below $20 \mathrm{~cm}$, the sediment is anaerobic and sulphidic. Hence, sulphide concentrations depend on the edaphic conditions controlling decay processes and appear to be a consequence rather than a cause of the observed zonation of vegetal species. The small size of $A$. geminans propagules might have a significant influence on the extensive development of this plant community along the highly dynamic coastline of the Guianas. This study demonstrates that the different properties of pore-water were intimately linked and that the explanation of the evolution of this forest reflects a combination of multiple parameters. Moreover, it appeared that the organic content played a key role along with the species composition and the seasonal variations (waterlogging, desiccation).

Author Keywords: mangrove; salinity; redox; pH; sulphide; French Guiana 


\section{Introduction}

Major questions in mangrove geochemistry concern the reciprocal interactions between sedimentary substrate and the vegetation (McKee, 1993). Salinity, redox potential, pH and sulphide concentration are pore-water parameters that play key roles in the development of mangroves and their spatial distributions. To cope with the variation of these properties, mangroves have developed many adaptations that give them wide ranges of tolerance. These adaptations result in geochemical modifications in the sediment. Additionally, climate, tidal flooding, vegetation evolution, bioturbation and organic matter content are parameters that also contribute to the complexity of the geochemistry of mangrove inhabited deposits.

Guiana mangrove is predominantly composed of Avicennia geminans and Rhizophora mangle and very scarce Laguncularia racemosa, which all develop on fine-grained sediment. This sediment comes from the huge mud discharge of the Amazon River, partly deflected northwestward by the current of the Guianas, moving towards the Orinoco River in the form of a series of mudbanks. The dynamic aspects of this coastline result in two main characteristics: (i) mangrove lifetime is limited (30-50 years) due to the speed of mudbank movement (1.4 km/year) (Allison et al., 2000), (ii) the constant remobilization of the sediment gives it suboxic properties (Aller, 1998).

Avicennia and Rhizophora are among the most widespread mangrove genera in the world, and the relations between mangrove genera and sediment geochemistry have been widely investigated (Hesse, 1961b; Baltzer, 1975; McKee, 1993; Lacerda et al., 1995; Pezeshki et al., 1997 and Alongi et al.., 2000). The two main axes of research are, on the one hand, the impact of physicochemical properties on mangrove zonation (Snedaker, 1982; Youssef and Saenger, 1999 and Matthijs et al., 1999), and on the other hand, the study of various redox processes in relation to the organic content (Hesse, 1961a; Pezeshki et al., 1997; Clark et al., 1998; Alongi et al., 1998 and Alongi et al.., 1999). Various factors have been pointed out that influence the zonation of mangrove species. Salinity is recognized as a factor influencing the zonation of species in many places (Walsh, 1974). The specific properties of propagules, namely their dispersal characteristics (Rabinowitz, 1978), their mass arrival linked to individual storms (Egler, 1948) and their resistance to consumption by predators (Smith et al., 1989) help explain many features of mangrove zonation. Flood tolerance (Naidoo, 1985 and McKee, 1993) and altitude of ground surface (Baltzer, 1969 and Chapman, 1976) also indirectly control zonation. Nickerson and Thibodeau (1985) described a strong correlation between the distribution of Rhizophora and Avicennia mangroves and the amount of hydrogen sulphide in the sediment, such that $A$. geminans would appear in areas of high sulphide concentration. In 1988, McKee et al. obtained contradictory results in mangroves associated with the 
Belizean barrier reef, as did Matthijs et al. (1999), in Gazy Bay (Kenya). These studies underscore the fact that mangrove zonation in general cannot be explained as a result of one single parameter (Youssef and Saenger, 1999). Rhizophora and Avicennia sharply differ in the way they influence sediment geochemistry (Alongi et al., 2000). For instance, the ability of Avicennia to oxidize sediment explains how aerobic respiration is a predominant agent of early diagenesis (Scholander et al., 1955). Clark et al. (1998) attributed the "lower oxidation zone" of their redox stratification model to the activity of the radial cable roots of Avicennia; while the "upper oxidation zone" was attributed to animal bioturbation. In a previous study (Marchand et al., 2003), we observed an increase in Eh values correlated with the forest development. All these studies demonstrate close links between plants and substrates.

Our knowledge of the biogeochemistry of mangrove sediment along the coastline of the Guianas is relatively poor due to the lack of published studies (Marchand et al., 2003). Our first objective was to characterize selected physicochemical properties of sediments in this environment to examine possible reciprocal relationships between plant and sediment. Subsequently, we investigated the part played by the development of the forests and the content of their soils in organic matter, the impact of seasons (rain, freshwater influx, evaporation), and the frequency of tidal flooding in modifying the geochemistry of the sediment.

To achieve this, we carried out field measurements in several areas of French Guiana, under forests composed of pure and mixed stands of different species of mangrove, at various stages of their development, different seasons, and at increasing distances from the shores and the estuaries.

\section{Materials and methods}

\subsection{Sites studied}

The mangroves studied are located: (i) on the right bank of the Sinnamary River, $50 \mathrm{~km}$ northwest of Kourou, (ii) at the mouth of the Kaw River, $30 \mathrm{~km}$ southeast of Cayenne, French Guiana (Fig. 1). These mangroves develop on huge mud banks, up to $30 \mathrm{~km}$ long (total length of one bank) and up to $5 \mathrm{~km}$ wide. The zonation of mangrove species, commonly observed in many regions, displaying Rhizophora on the seaward fringe and Avicennia behind it in a zone of higher elevation (Hesse, 1961b; Baltzer, 1969; Chapman, 1976; McKee, 1995 and Blasco et al., 1996), does not occur in French Guiana. In contrast, in French Guiana, the seaward zone exhibits quasi-unispecific swamps (A. geminans) whose limits parallel the shoreline. Small, scattered L racemosa stands locally fringe the seaward side in the vicinity of minor river outlets. R. mangle stands are present inside the estuaries or as patches in senescent Avic ennia forests, both sites being sheltered and submitted to fresh water influxes. The senescent Avic ennia forests are also characterized by the development of epiphytes, creepers and pteridophytes. Some Acrostic hum 
aureum colonize the senescent and the dead mangroves. Field observations in both situations reveal that pioneer and young mature mangrove forests are reached by every flood tide. In contrast, the mature Avic ennia zone displays a higher topography which prevents all but spring tides from overflowing its soils and reaching the senescent mangrove. Thus, a sheet of freshwater covers the mature and senescent mangroves during rainy seasons. The various developmental stages of the Avicennia-dominated mangrove of Sinnamary have been described relative to their structural and biological features (Fromard et al., 1998). These mangrove forests are not subject to anthropogenic exploitation.

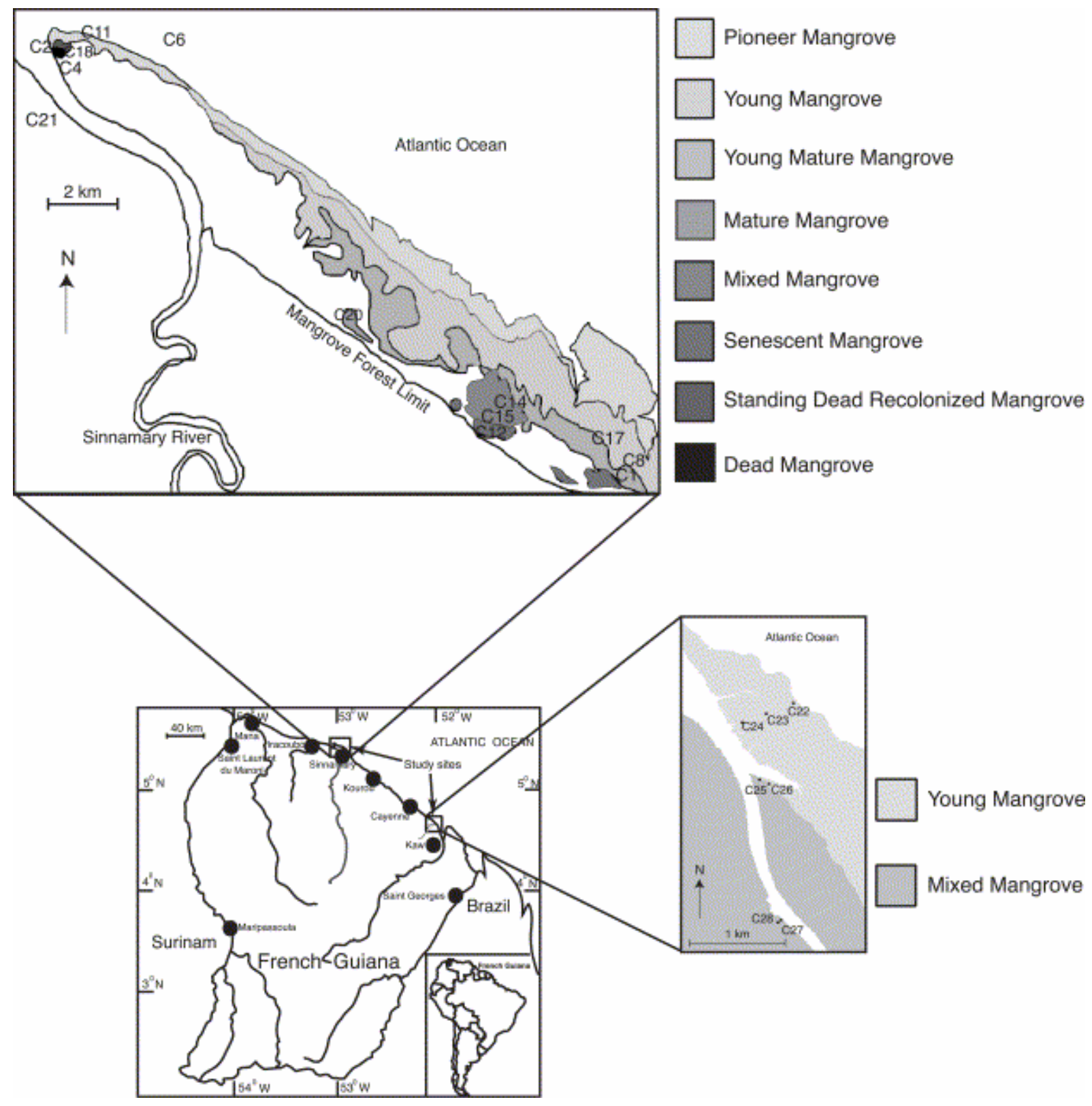

Fig. 1. Map of the studied area showing the location of cores (adapted from Fromard et al., 1998). 


\subsection{Climate}

French Guiana $\left(2-6^{\circ} \mathrm{N}\right)$ is characterized by a subequatorial climate with a mean annual rainfall ranging from 2500 to 3000 mm/year (Fig. 2) occurring in a bimodal pattern. The major rainfall period extends from late March to early July, peaking in May, when the Inter Tropical Convergence Zone (ITCZ) passes over French Guiana. The minor wet season begins in late November and finishes in late January, when the ITCZ passes over Guiana. The average air temperature fluctuates between 26 and $30^{\circ} \mathrm{C}$. The mean annual total insolation is of $2200 \mathrm{~h}$, culminating in October (Meteo France). However, annual variations can be very high, and seasons can shift several weeks before or after, or be skipped altogether. Tides are semi-diurnal with a tidal range of $1.8 \mathrm{~m}$ (SHOM, 2001).

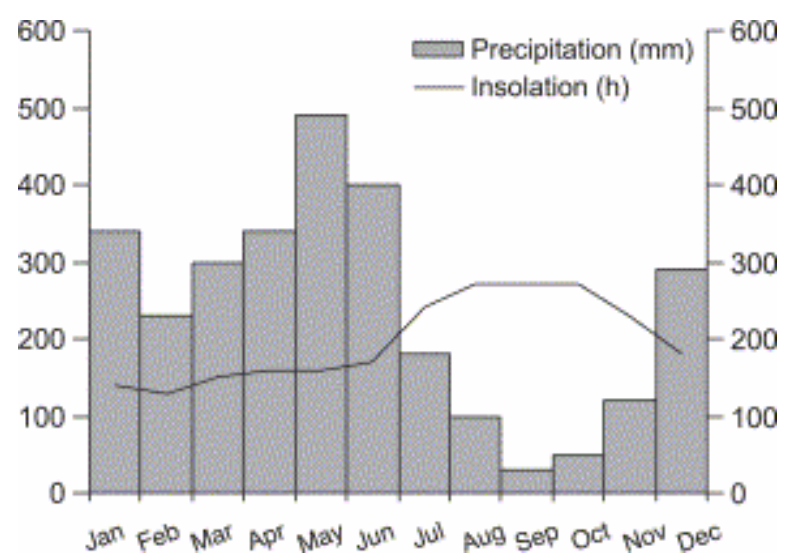

Fig. 2. Mean monthly distribution of rainfall and insolation along the coastline of French Guiana (mean values on 30 years) (Meteo France Guyane).

\subsection{Sampling and measurements}

Cores were collected at low tide with an Eijkelkamp gouge auger in 28 areas defined in terms of vegetation composition, stage of development and location in the swamp; data obtained from 20 gouge cores are presented herein. Work was carried out in four fieldtrips, during which five areas were sampled repeatedly as a function of season. One core was collected at the end of the dry season (October 1997), 12 cores were sampled during the "short summer" (March 2000), 11 cores were collected at the end of the rainy season (July 2001) and 9 cores in January 2002, 2 weeks after the end of an exceptionally long dry season (which would have ended in November under usual circumstances). The positions and characteristics of the 20 areas are listed in Iable 1. Depending on field conditions, most cores were duplicated. In the A. gemina ns forests, core locations were chosen equidistant from trees, in consideration of the large extension of the radial cable roots. In the R. mangle forests, cores were collected under prop roots. After collection, cores were wrapped in plastic film and aluminium foil in order to limit gas exchange and returned to an air-conditioned laboratory. Samples were taken at the following depth intervals (in cm): $2 \mathrm{~cm}$ from 0 to $20 \mathrm{~cm}, 5 \mathrm{~cm}$ from 20 to $60 \mathrm{~cm}$ 
then every $20 \mathrm{~cm}$ and kept refrigerated. Sampling of mud and measurements of physicochemical parameters (Eh, pH, salinity and sulphide electrode potential) were performed in duplicate on the day of coring. Probes were inserted in the center of core sample intervals in order to avoid air contact.

\begin{tabular}{|c|c|c|c|c|c|}
\hline Stribe & Loousoe (UTM 22 N) & Period of sampling & Descripose of aras & Sage of ferest evolusioe & Chancteristios \\
\hline $\mathrm{Cl}$ & $295562 \mathrm{E}-591549 \mathrm{~N}$ & $\begin{array}{l}\text { October } 1997 \\
\text { Maxh } 2000 \\
\text { July } 2001 *\end{array}$ & A. germiteas; $20 \mathrm{~m}$ bigh & "Young" mature forest & $\begin{array}{l}\text { Fooded at and side; } \\
\text { firthest from the sbore }\end{array}$ \\
\hline $\mathrm{C} 2$ & $278941 \mathrm{E}-602118 \mathrm{~N}$ & $\begin{array}{l}\text { Maxb } 2000 \\
\text { July } 2001 *\end{array}$ & $\begin{array}{l}\text { A. germinass; standing } \\
\text { dead trees; } \\
4 \mathrm{~m} \text { high }\end{array}$ & $\begin{array}{l}\text { "Rooolceined" } \\
\text { cemetery foost }\end{array}$ & Fooded at anch side \\
\hline C4 & $278953 \mathrm{E}-602048 \mathrm{~N}$ & $\begin{array}{l}\text { Maxh } 2000 \\
\text { July } 2001 \text {. }\end{array}$ & $\begin{array}{l}\text { Stroding dend tees; } \\
\text { Ac. awream }\end{array}$ & Cometery ferest & Fooded at anch side \\
\hline c6 & $290526 \mathrm{E}-602944 \mathrm{~N}$ & $\begin{array}{l}\text { Maxh } 2000^{\circ} \\
\text { July } 2001^{*}\end{array}$ & Sbocefice sediment & & \\
\hline $\mathrm{Cs}$ & $295692 \mathrm{E}-591402 \mathrm{~N}$ & Maxb $2000^{\circ}$ & A. germikas;; $10 \mathrm{~m}$ bigh & Young foosest & Flooded at anch side \\
\hline $\mathrm{Cil}$ & $278961 \mathrm{E}-602 \mathrm{181} \mathrm{N}$ & $\begin{array}{l}\text { Maxh } 2000^{*} \\
\text { July } 2001^{*}\end{array}$ & A. germitaks; $1 \mathrm{~m}$ bigh & Psoced forest & $\begin{array}{l}\text { Flooded at anch side; } \\
\text { dooest to the shore }\end{array}$ \\
\hline $\mathrm{C} 12$ & $290301 \mathrm{E}-59298 \mathrm{~N}$ & $\begin{array}{l}\text { Maxb } 2000 \\
\text { July } 2001 *\end{array}$ & $\begin{array}{l}\text { A. germinass; coiphytes, } \\
\text { crepes and poenidophytes; } \\
30 \mathrm{~m} \text { high }\end{array}$ & Senescent forest & $\begin{array}{l}\text { Fooded at speing bide; } \\
\text { coverd by frest waxe }\end{array}$ \\
\hline $\mathrm{Cl4}$ & $291009 \mathrm{E}-592914 \mathrm{~N}$ & July $2001^{*}$ & A. germinass; $R$. mangle & Mixed mature forest & $\begin{array}{l}\text { Flooded at speing bide; } \\
\text { coverd by fosh wax }\end{array}$ \\
\hline C15 & $290931 \mathrm{E}-992920 \mathrm{~N}$ & July $2001^{*}$ & A. germisass: $R$. mangle & Mixod mature forest & $\begin{array}{l}\text { Fooded at speing bide; } \\
\text { covered by fosh waxe }\end{array}$ \\
\hline $\mathrm{C} 17$ & $295568 \mathrm{E}-592511 \mathrm{~N}$ & July $2001 *$ & A. germisaks; $20 \mathrm{~m}$ bigh & "Young" mature forest & Flooded at anch side \\
\hline $\mathrm{C} 18$ & $278959 \mathrm{E}-602154 \mathrm{~N}$ & July $2001 *$ & A. germisass; $10 \mathrm{~m}$ bigh & Young fooest & Fooded at anch side \\
\hline $\mathrm{C} 20$ & $287161 \mathrm{E}-594977 \mathrm{~N}$ & January $2002^{*}$ & A. germikass; $25 \mathrm{~m}$ bigh & Marure foost & Covered by teeb wret \\
\hline $\mathrm{C} 21$ & $278607 \mathrm{E}-599648 \mathrm{~N}$ & Jazuary $2002^{\circ}$ & 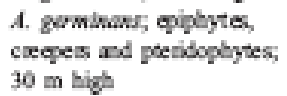 & Senescent forest & Covered by test writer \\
\hline $\mathrm{C}_{22}$ & $374676 \mathrm{E}-529$ a5 N & January $2002^{*}$ & A. germisass; $10 \mathrm{~m}$ bigh & Young fooest & Flooded at anch side \\
\hline $\mathrm{C}_{23}$ & $374411 \mathrm{E}-529528 \mathrm{~N}$ & January $2002^{\circ}$ & A. gerwikass; $10 \mathrm{~m}$ bigh & Young foost & Fooded at anch bide \\
\hline $\mathrm{C}_{24}$ & $374144 \mathrm{E}-529436 \mathrm{~N}$ & Jazunary $2002^{*}$ & A. germitass & Young fooest & Flooded at anch side \\
\hline $\mathrm{C2S}$ & $374343 \mathrm{E}-528867 \mathrm{~N}$ & January $2002^{*}$ & Young $R$. mangle & Young foost & Flooded at anch side \\
\hline $\mathrm{C}_{26}$ & $374451 \mathrm{E}-528823 \mathrm{~N}$ & January $2002^{*}$ & A. germitaks; $10 \mathrm{~m}$ bigh & Young foosst & Flooded at anch bide \\
\hline $\mathrm{C}_{27}$ & $374 \$ 45 \mathrm{E}-527595 \mathrm{~N}$ & January $2002^{*}$ & R. maxgle & Young foost & $\begin{array}{l}\text { Fside the estury; } \\
\text { tiver levee }\end{array}$ \\
\hline $\mathrm{C} 28$ & $374561 \mathrm{E}-527588 \mathrm{~N}$ & January $2002^{*}$ & $\begin{array}{l}\text { R. mangle soaxe } \\
\text { A. germitaks }\end{array}$ & Mixed mature focest & Eside the estury \\
\hline
\end{tabular}

- Cores pefoemed at thr. period ware duplicaned.

Table 1. Characteristics of the various mangrove forests studied

Salinities were determined using an Atago refractometer after extracting a drop of interstitial water from the core (through filter paper in a hand press). $\mathrm{pH}$ was measured $\left(\mathrm{T}=25^{\circ} \mathrm{C}\right)$, using a glass electrode and a Knick Portamess $\mathrm{pH}$ meter, by inserting the probes directly into the tested mud through openings cut in the plastic and aluminium liners. The $\mathrm{pH}$ electrode was calibrated using 4 and 7 standards (NIST scale). Redox potential was measured, using a combined $\mathrm{Pt}$ and $\mathrm{Ag} / \mathrm{AgCl}$ (reference) electrode connected to a WTW $\mathrm{pH} / \mathrm{mV} / \mathrm{T}$ meter. The redox electrode was periodically checked using a $0.43 \mathrm{~V}$ standard solution and demineralized water. Electrodes were inserted for several minutes in the mud until stable values were reached, then were thoroughly washed and subsequently rubbed with fine emery paper after each measurement in order to prevent the poisoning of electrodes by sulphide (Garrels and Christ, 1965). Redox data are reported relative to a standard hydrogen electrode, i.e., after adding $202 \mathrm{mV}$ to the original $\mathrm{mV}$ values obtained with an $\mathrm{Ag} / \mathrm{AgCl}$ reference electrode (at $25^{\circ} \mathrm{C}$ ). 
The same instrument with a sulphide ion specific electrode and a double junction reference electrode was used for the detection of sulphide. Porewater was extracted during this study, but not protected from atmospheric oxygen contamination to allow electrode titration (Green and Schnitker, 1974) or gas stripping analysis of total sulphide (Albéric, 1976). The aim was to measure an electrochemical signal indicating the sulphide richest layers in mud cores by direct insertion of electrodes, rather than to precisely determine sulphide concentrations in pore-water. Nevertheless, sulphide ion activities derived from electrodes potentials were converted to total sulphide concentrations taking into account variations of $\mathrm{pH}$ and ionic strength (Orion Research, 1970). Ionic strength was derived from salinity (Vismann, 1996). The calibration of the electrodes was performed by titration of sulphide solutions (prepared with $\mathrm{Na}_{2} \mathrm{~S} \cdot 9 \mathrm{H}_{2} \mathrm{O}$ PROLABO) by a standard $\mathrm{AgNO}_{3}$ solution $\left(\log \left(S^{-}\right)=-0.027 E_{A g S} / A_{2} 25-21.23\right)$. Although, polysulphides are likely to occur in oxygenated sulphide solutions (Boulègue and Michard, 1973 and Boulègue, 1974) polysulphides were neglected in the computation of total sulphides from sulphide ion activities measured in the sediment and during the calibration procedure by $\mathrm{Ag}^{+}$titration. The association of sulphide concentration and total sulphur in sediment was used as a proxy of sulphate reduction. Values of physicochemical parameters presented herein are mean values between duplicated cores.

Total carbon and total sulphur contents were determined by combustion at $1100{ }^{\circ} \mathrm{C}$ with a CNS-2000 LECO apparatus. Due to the nearly total lack of carbonates, total carbon can be attributed to the total organic carbon. Total carbon values of the various sites are reported in $\underline{\text { Table } 2}$.

\begin{tabular}{|c|c|c|c|c|c|}
\hline Staboe-year & $\mathrm{Cl}-01$ & $\mathrm{C} 2-01$ & C4-01 & $C 6-\infty$ & $C 8-\infty$ \\
\hline Period of sampling & July 2001 & July 2001 & July 2001 & Mrch 2000 & March 2000 \\
\hline \multicolumn{6}{|c|}{ Organis carbow consent (\%) } \\
\hline Tog w $5 \mathrm{~cm}(n=2 \times 2)$ & $2.41 \pm 0.49$ & $2.23 \pm 0.20$ & $1.73 \pm 0.49$ & $\alpha \pi \pm 0.02$ & $1.39 \pm 0.12$ \\
\hline $5-40 \mathrm{~cm}(\mathrm{k}=2 \times 11)$ & $1.28 \pm 0.62$ & $207 \pm 0.79$ & $1.61 \pm 0.55$ & $0.75 \pm 0.01$ & $0.87 \pm 0.04$ \\
\hline $40-100 \mathrm{~cm}(\kappa=2 \times 7)$ & $0 \pi 7 \pm 0.07$ & $2.05 \pm 0.62$ & $1.19 \pm 0.60$ & $0.72 \pm 0.02$ & $0.90 \pm 0.12$ \\
\hline Staboe-year & C11- -0 & C12-01 & C14-01 & C15-01 & C17-01 \\
\hline Period of sampling & March 2000 & July 2001 & July 2001 & July 2001 & July 2001 \\
\hline \multicolumn{6}{|c|}{ Organis carbow consent (\%) } \\
\hline $\operatorname{Tog} \cos \mathrm{cm}(n=2 \times 2)$ & $1.11 \pm 0.47$ & $10.31 \pm 5.36$ & $15.7 \pm 8.25$ & $21.6 \pm 226$ & $1.68 \pm 0.48$ \\
\hline $5-40 \mathrm{~cm}(s=2 \times 11)$ & $077 \pm 0.03$ & $3.14 \pm 1.06$ & $2.98 \pm 1.02$ & $4.7 \pm 3.38$ & $1.06 \pm 0.22$ \\
\hline $40-100 \mathrm{~cm}(n=2 \times 7)$ & $0.76 \pm 0.02$ & $0.86 \pm 0.10$ & $0.92 \pm 0.10$ & $0.92 \pm 0.01$ & $0.78 \pm 0.08$ \\
\hline Stasioe-year & $\underline{\mathrm{C} 18-01}$ & $\mathrm{C} 20-02$ & $\mathrm{C}_{21-02}$ & $\mathrm{C}_{22}-02$ & $\mathrm{C}_{23}-\omega_{2}$ \\
\hline Period of sampling & July 2001 & January 20002 & January 2002 & Jauray 20002 & Janurxy 2002 \\
\hline \multicolumn{6}{|c|}{ Organis carbow consent (\%) } \\
\hline Tog to $5 \mathrm{~cm}(n=2 \times 2)$ & $134 \pm 0.17$ & $7.90 \pm 0.82$ & $9.93 \pm 2.85$ & $1.65 \pm 0.55$ & $0.92 \pm 0.08$ \\
\hline $5-40 \mathrm{~cm}(\mathrm{~s}=2 \times 11)$ & $081 \pm 0.17$ & $5.44 \pm 1.19$ & $1.91 \pm 1.16$ & $0.81 \pm 0.21$ & $0 . \pi \pm 0.12$ \\
\hline $40-100 \mathrm{~cm}(n=2 \times 7)$ & $078 \pm 0.05$ & $1.49 \pm 0.65$ & $1.48 \pm 0.51$ & $0.71 \pm 0.07$ & $0.09 \pm 0.06$ \\
\hline Stabien-year & $\mathrm{C24-02}$ & $\mathrm{C} 2 \mathrm{~S}-02$ & $\underline{\mathrm{C}} 26-02$ & $\underline{\mathrm{C} 27-02}$ & $\mathrm{C} 28-02$ \\
\hline Period of sampling & Javaray 2002 & January 2002 & January 2002 & Jaurary 2002 & Janurary 2002 \\
\hline \multicolumn{6}{|c|}{ Organs carbow consent (\%) } \\
\hline $\operatorname{Tog} 05 \mathrm{~cm}(n=2 \times 2)$ & $101 \pm 0.19$ & $4.37 \pm 0.02$ & $1.88 \pm 0.07$ & $224 \pm 0.20$ & $3.16 \pm 0.94$ \\
\hline $5-40 \mathrm{~cm}(s=2 \times 11)$ & $078 \pm 0.12$ & $2.65 \pm 0.94$ & $1.05 \pm 0.42$ & $1.88 \pm 0.64$ & $1.91 \pm 0.68$ \\
\hline $40-100 \mathrm{~cm}(n=2 \times 7)$ & $075 \pm 0,09$ & $1.56 \pm 0.5$ & $0.81 \pm 0.08$ & $1.35 \pm 0.44$ & $1.75 \pm 0.35$ \\
\hline
\end{tabular}

Table 2. Mean sedimentary organic content of the various mangrove forests 


\section{Results}

\subsection{Salinity}

Salinity varied significantly among the various sites, with depth and with seasons. Measurements done at the end of the rainy season in Sinnamary, at places where A. geminans is predominant, exhibited a downward salinity increase in the form of four different depth patterns depending on plant development and position in the mangrove swamps:

(i) at the mouth of the estuary, salinities of both pioneer ( $\mathrm{Cl} 11)$ and dead mangroves (C4) increased in a regular way from 6 at the top to 23 at $80 \mathrm{~cm}$ depth (Fig. 3a);

(ii) slightly farther from the mouth of the estuary, in the young forest $(\mathrm{C} 18)$ and in the dead, recolonized forest (C2), salinity stabilized below $30 \mathrm{~cm}$ deep, reaching 38 (Fig. 3a);

(iii) in the young mature mangrove $(\mathrm{Cl}, \mathrm{C} 17)$, which, being far from the shore, were not subject to fresh water influxes, salinity showed its largest variation with depth, and increased from nearly 20 at the top to more than 50 at $40 \mathrm{~cm}$ and stabilized below (Fig. 3b);

(iv) in the mixed mature forests $(\mathrm{C} 14, \mathrm{C} 15)$ and the senescent forest $(\mathrm{C} 12)$, which were subject to continental freshwater discharge, salinity was very low $(<5)$ in the uppermost $20 \mathrm{~cm}$, and increased to 30 at $60 \mathrm{~cm}$ depth (Fig. $3 \mathrm{c}$ ) 

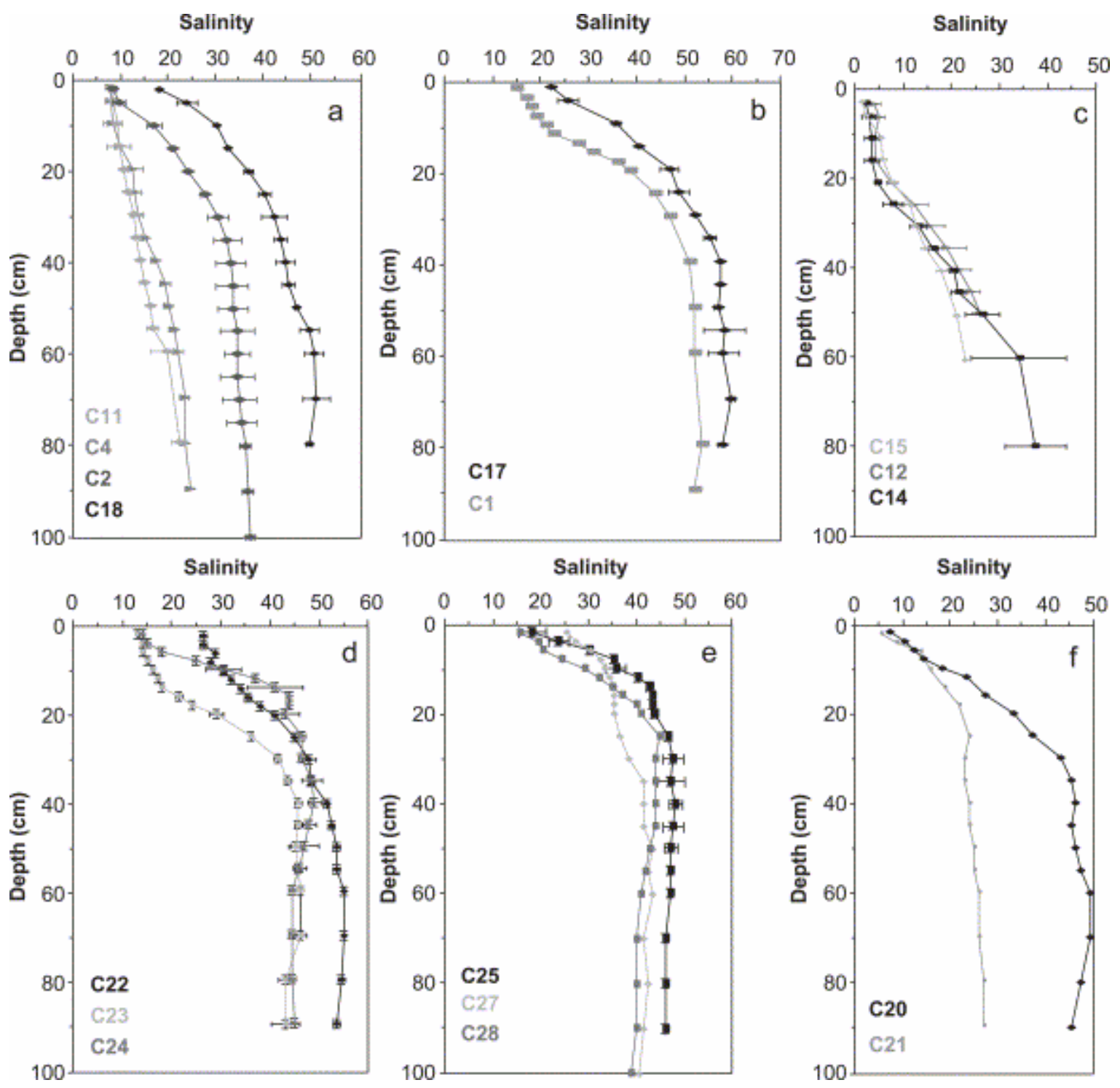

Fig. 3. Depth distribution of salinity beneath different mangrove forests. Mean values on duplicated cores. (a) Pioneer (11), young (18), cemetery (4) and recolonised cemetery (2) A. geminans mangrove, Sinnamary River mouth, July 2001; (b) young mature A. geminans mangrove forest, tidally inundated, interior stand, Sinnamary, July 2001; (c) mixed mature forest $(14,15)$ and senescent forest (12), interior stand, near fresh water source, Sinnamary, July 2001; (d) young A. geminans mangrove forest, Kaw River mouth, January 2002; (e) young R. mangle mangrove forest, Kaw, January 2002; (f) mature (20) and senescent (21) A. geminans mangrove forest, Sinnamary, interior stand, near fresh water source, January 2002.

Consequently, provided that mangrove was not exposed to fresh water influx, salinity increased with plant development. In addition, salinity values revealed strong seasonal variations. At the end of the dry season (year 1997), in the young mature Avicennia forest (C1), salinity was very high over the whole depth profile, ranging from 50 to 60 (Fig. 4a). Seasonal variations were smaller between the rainy season (2001) and the "short summer" in places where mangroves were submitted to fresh water flow (Fig. 4b,c,d). In the Kaw estuary (January 2002), salinity values measured on cores from young Avicennia mangrove forests $(C 22, C 23, C 24)$ and from Rhizophora stands 
(C25, C27, C28) also exhibited an increase with depth, with values exceeding 50 (Fig. 3d).
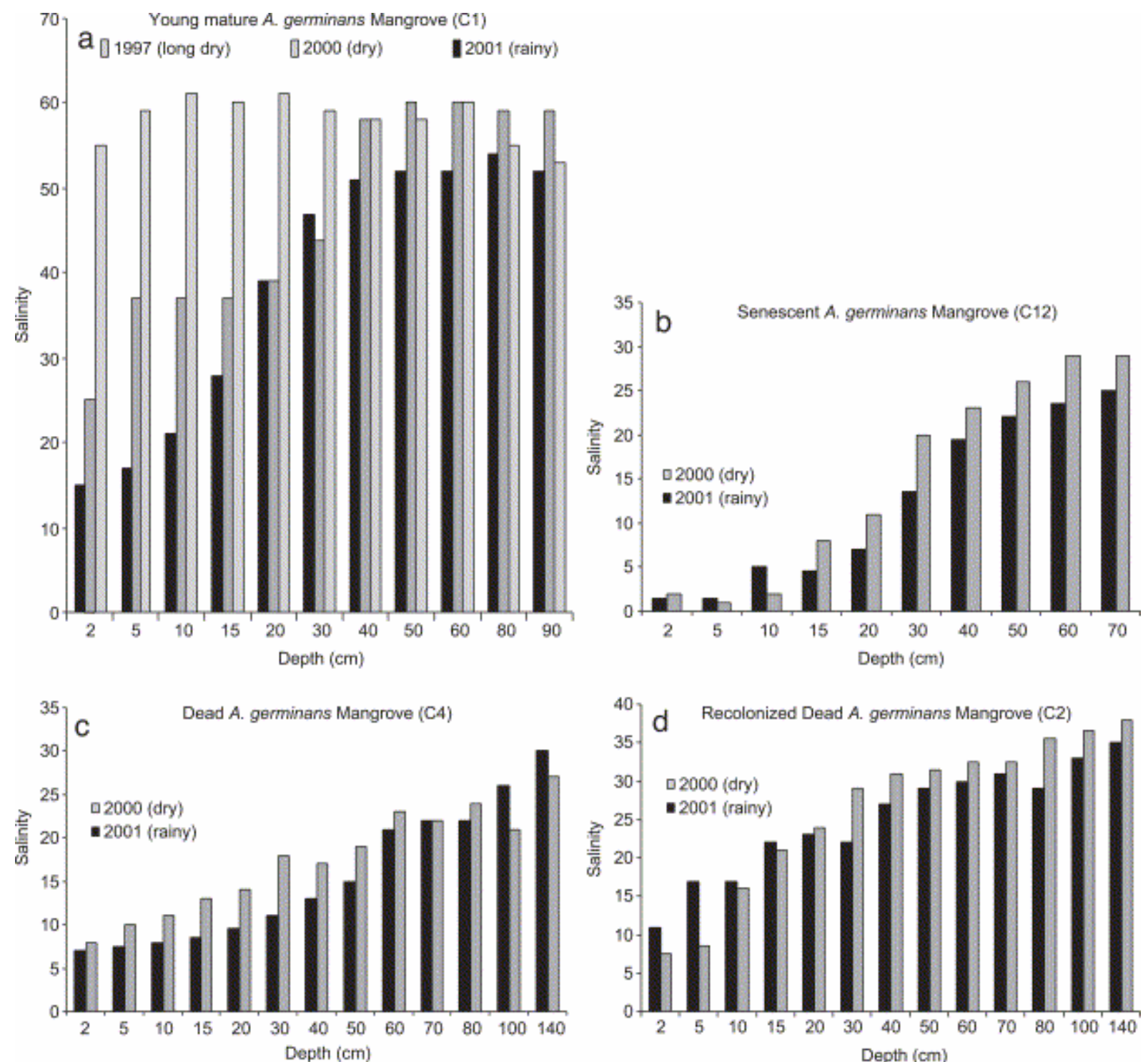

Fig. 4. Seasonal evolution of salinity beneath different mangrove forests in Sinnamary. (a) Young mature A. geminans mangrove forest, Sinnamary, October 1997, March 2000 and July 2001; (b) dead A. geminans mangrove forest, March 2000 and July 2001; (c) senescent A. geminans mangrove forest, March 2000 and July 2001; (d) recolonized cemetery A. geminans mangrove forest, March 2000 and July 2001.

\section{2. $\mathrm{pH}$}

Changes in $\mathrm{pH}$ values were observed as a function of depth and season. The $\mathrm{pH}$ measurements performed on shoreface sediment (C6) remained stable with depth (around 6.7). Sediments from the dead (C4) and the pioneer (C11) mangrove at the mouth of the Sinnamary estuary also exhibited pHs that were stable with depth (Fig. 5a). All mangroves subject to daily tidal immersions, i.e., pioneer to young mature A. geminans mangrove forests $(\mathrm{C} 11, \mathrm{C} 8, \mathrm{C} 17, \mathrm{C} 1, \mathrm{C} 24, \mathrm{C} 26)$, displayed similar distributions of $\mathrm{pH}$ vs. depth 
(Fig. 5a,b). Measurements indicated mild acidic conditions, pHs ranging from 6.5 to 6.9 with low around a depth of $15 \mathrm{~cm}$. Below $40 \mathrm{~cm}$ in depth, $\mathrm{pH}$ was stable. Seasonal variations were very limited beneath these young mangroves (Fig. 6a). In contrast, pH variations were higher in the older, landward parts of mangrove forests that were flooded at spring tides only and submitted to surface and underground fresh water influxes, especially during wet seasons. These mangroves were also characterized by a sedimentary organic content invariably higher than average. Measurements in mature plurispecific (C14, $\mathrm{C} 15)$ and senescent mangroves (C12), performed at the end of the rainy season yield markedly acidic $\mathrm{pH}$ values approaching 5 by the top of cores (Fig. $5 \mathrm{C})$. From there, the depth distribution of pHs increased logarithmically to 6.7 at $40 \mathrm{~cm}$ depth. Seasonal variations were also more pronounced during the short summer, when pH's were more acidic in the uppermost $40 \mathrm{~cm}$ (Fig. 6b). Measures done in January in the mature (C20) and senescent forest (C21) display a different pattern in the uppermost $20 \mathrm{~cm}$ (Fig. 5d). In fact, the most acidic values were at $15 \mathrm{~cm}$ depth rather than at the top of the core, and were close to 4.5 .
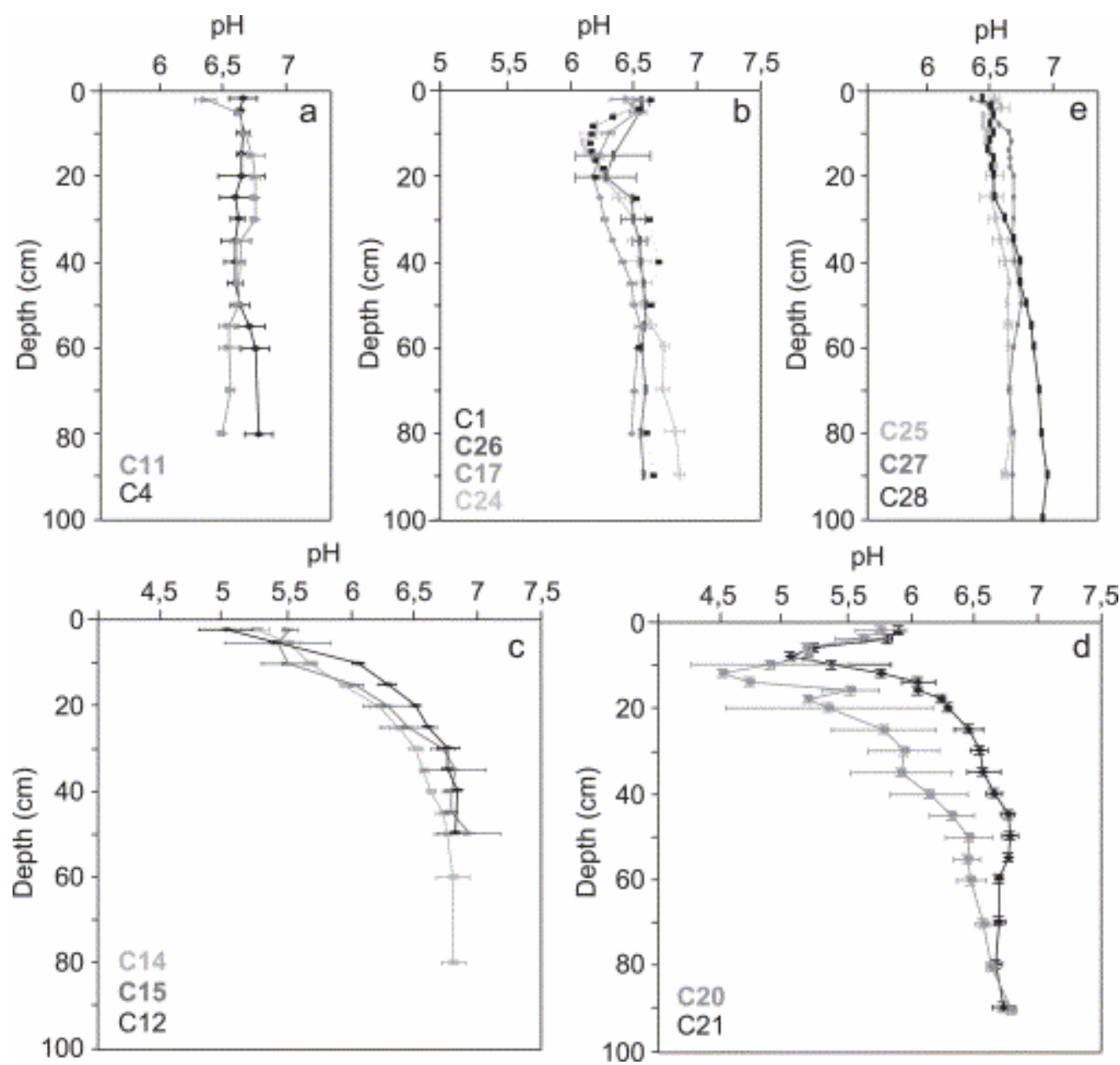

Fig. 5. Depth distribution of $\mathrm{pH}$ beneath different mangrove forests. Mean values on duplicated cores. (a) Shoreface sediment and dead mangrove; (b) pioneer to young mature A. geminans mangrove forest, flooded at each tide, low organic content, July 2001; (c) mixed mature and senescent mangrove, interior stand, high organic content, Sinnamary, July 
2001; (d) mature and senescent A. geminans mangrove forest, interior stand, high organic content, Sinnamary, January 2002; (e) young R. mangle mangrove forest, Kaw, January 2002.
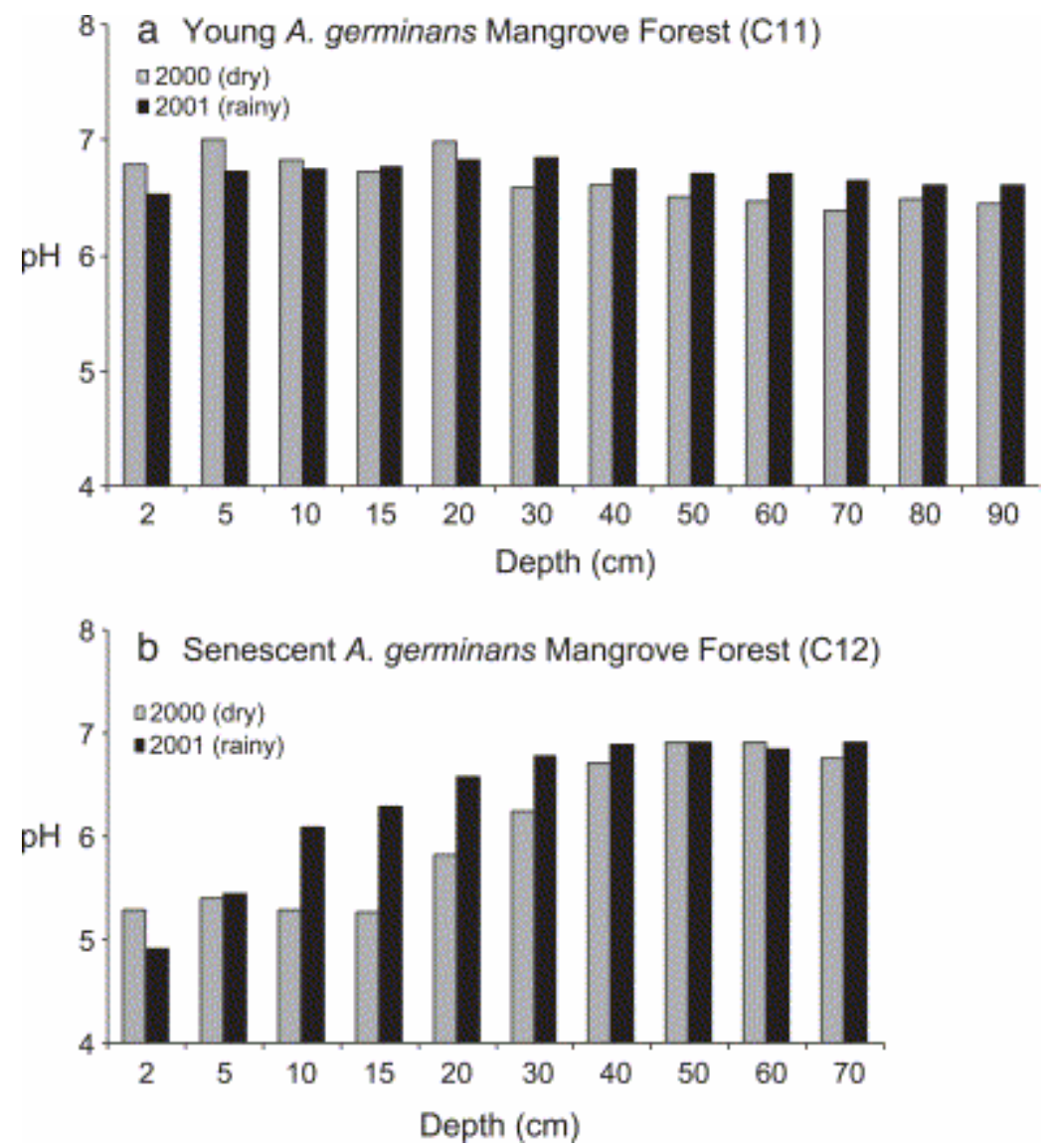

Fig. 6. Seasonal evolution of pH. (a) Young A. geminans mangrove forest, March 2000 and July 2001; (b) senescent A. geminans mangrove forest, March 2000 and July 2001.

In the same environmental conditions, no significant differences in $\mathrm{pH}$ were found between sediments beneath A. geminans (C25) and R. mangle (C26) (Fig. 5d,b,e).

\subsection{Redox potentials}

Redox potentials were very sensitive to seasonal changes, vegetal zones and depth. In shoreface sediment, Eh values ranged from 0 to $100 \mathrm{mV}$ (Fig. 7a). In Avic ennia forests at the first stages of their development, Ehs were significantly higher compared with redox values in shoreface sediments. In addition, an increase in Eh was recorded in the upper part of cores when passing from the pioneer to the young mature A. geminans mangrove forests during the short summer (Fig. 7b). Maximum values ranged from $200 \mathrm{mV}$ for the pioneer to 480 $\mathrm{mV}$ for the young mature forest. Below $40 \mathrm{~cm}$ depth, Eh values decreased significantly and stabilized around $50 \mathrm{mV}$. However, the redox potentials of these mangrove forests presented a high seasonal variability. In fact, during the rainy season, Ehs were low along the whole depth profile (Fig. 8a,b,c). However, the lowest figures occurred in the uppermost $10 \mathrm{~cm}$ and a relative 
high in redox values still existed between 10 and $20 \mathrm{~cm}$. Beneath R. mangle stands (C25, C27), maximum values close to $200 \mathrm{mV}$ were at the top of the core. Below this, redox potentials decreased rapidly, within a $5-\mathrm{cm}$ interval, to stabilize around $50 \mathrm{mV}$ (Fig. $7 \mathrm{f}$ ). Depth profiles of the mixed mature forest $(\mathrm{C} 14, \mathrm{C} 15)$ and the senescent mangrove $(\mathrm{C} 12)$ exhibited lower Eh values, decreasing from $200 \mathrm{mV}$ at the top to $0 \mathrm{mV}$ at $15 \mathrm{~cm}$ depth (Fig. 7d). In the senescent mangrove, Ehs varied slightly between the short summer and the rainy season. However, lowest values existed during the wet season between 10 and $40 \mathrm{mV}$ (Fig. 8d). Measurements performed beneath mature and senescent Avicennia stand in January 2002 produced redox potentials varying significantly with depth (Fig. 7e). Ehs increased in the uppermost 15 $\mathrm{cm}$ to reach high values, close to $400 \mathrm{mV}$, then decreased to stabilize around $100 \mathrm{mV}$. Whatever the season, Ehs were anti-correlated with pHs in mature and senescent mangrove forests, both plurispecific and Avicennia dominated (igi. 9).
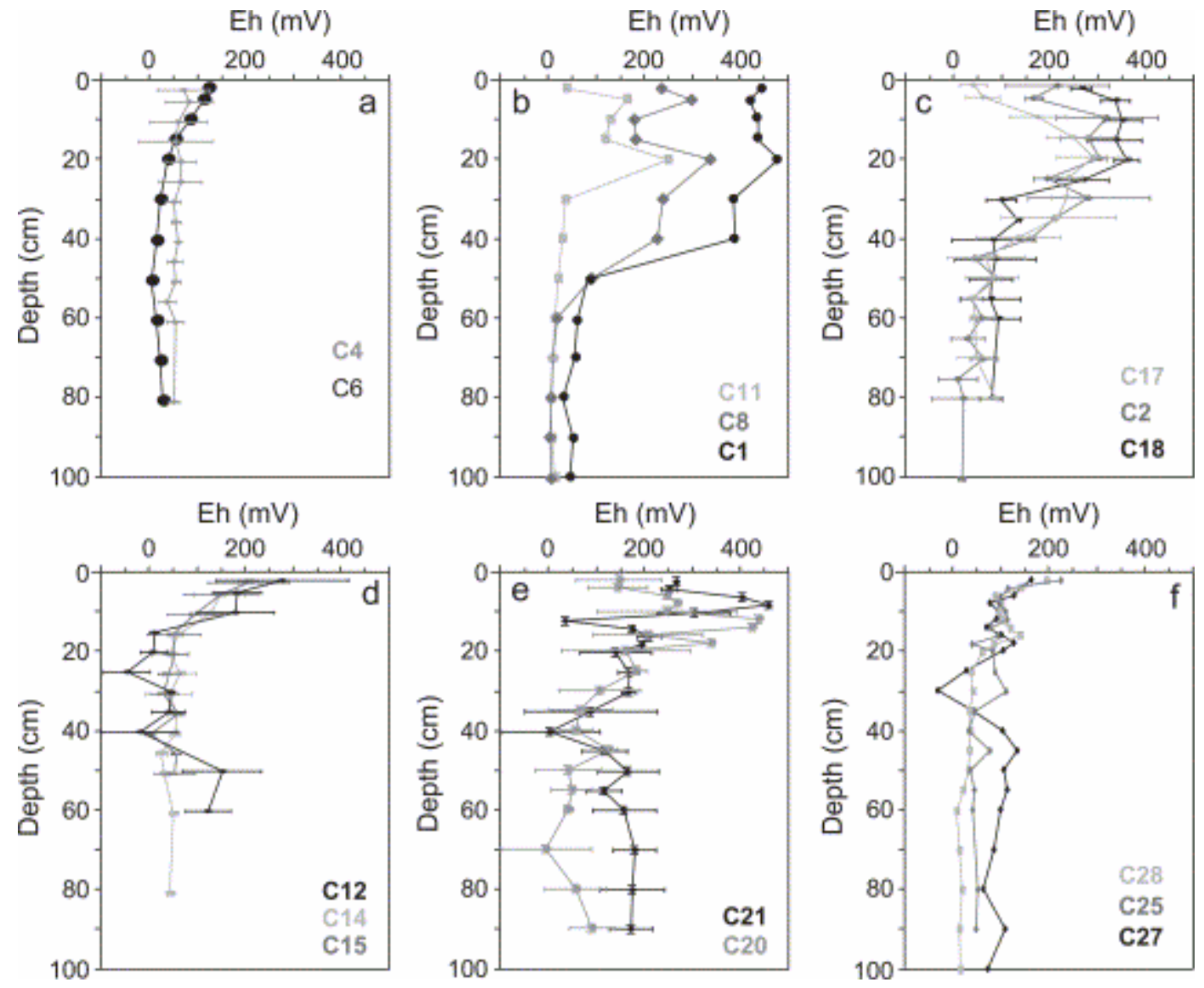

Fig. 7. Depth distribution of redox potential. Mean values on duplicated cores. (a) Shoreface sediment (C6) and dead forest (C4); (b) pioneer (C11), young (C8) and young mature (C1) A. geminans, flooded at each tide, low organic content, Sinnamary, March 2000; (c) young $(\mathrm{C} 17, \mathrm{C} 18)$ and recolonised cemetery (C2) A. geminans mangrove forest, flooded at each tide, low organic content, Sinnamary, July 2001; (d) mixed mature (C14, C15) and senescent (C12) mangrove, interior stand, high organic content, Sinnamary, July 2001; (e) mature (C20) and senescent (C21) A. geminans mangrove forest, interior stand, high organic content, Sinnamary, January 2002; (f) R. mangle forest, Kaw, January 2002. 

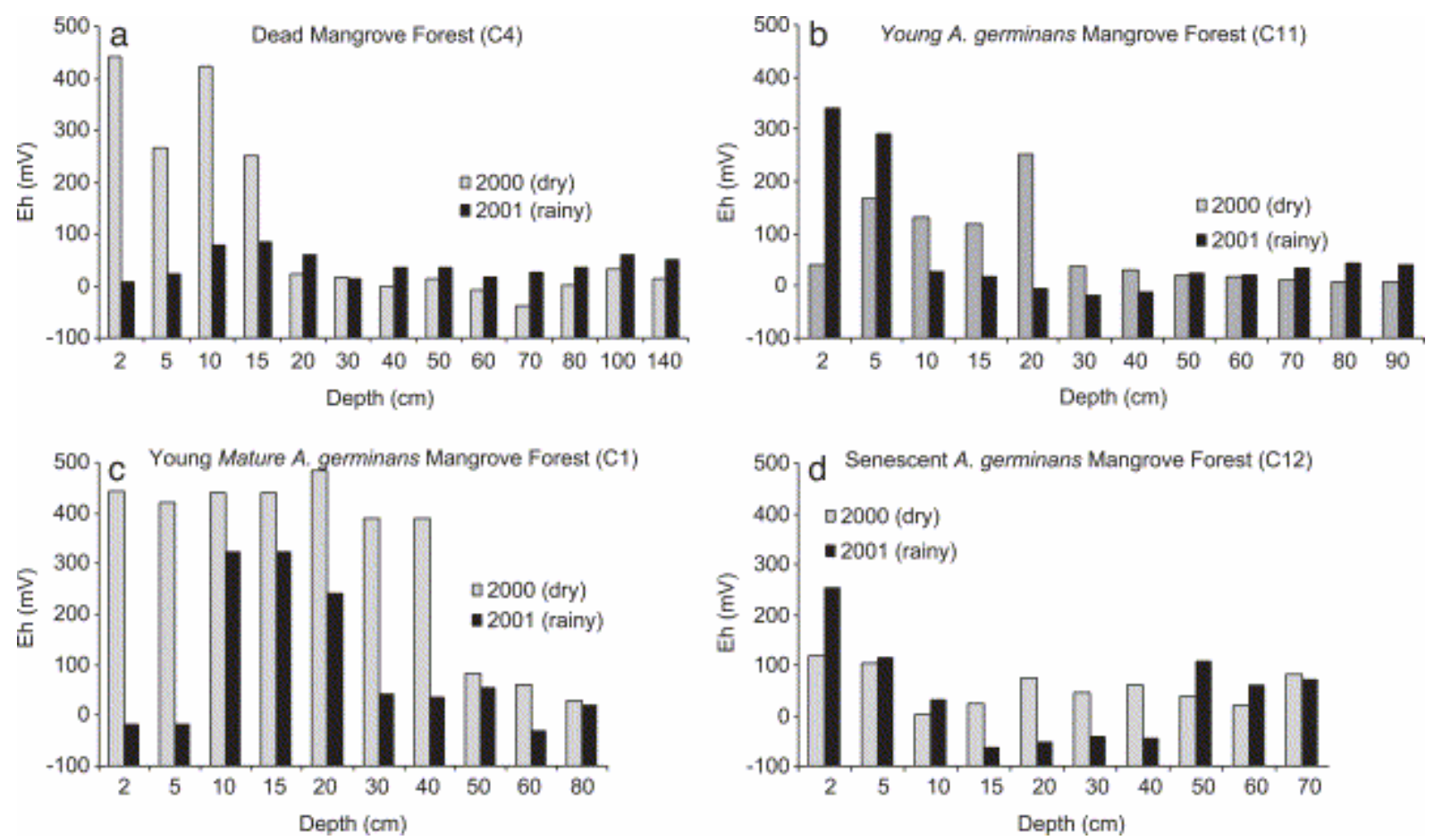

Fig. 8. Seasonal evolution of redox potential. (a) Dead forest, Sinnamary, March 2000 and July 2001; (b) young A. geminans mangrove forest, March 2000 and July 2001; (c) young mature A. geminans mangrove forest, Sinnamary, March 2000 and July 2001; (d) senescent A. germinans mangrove forest, March 2000 and July 2001.

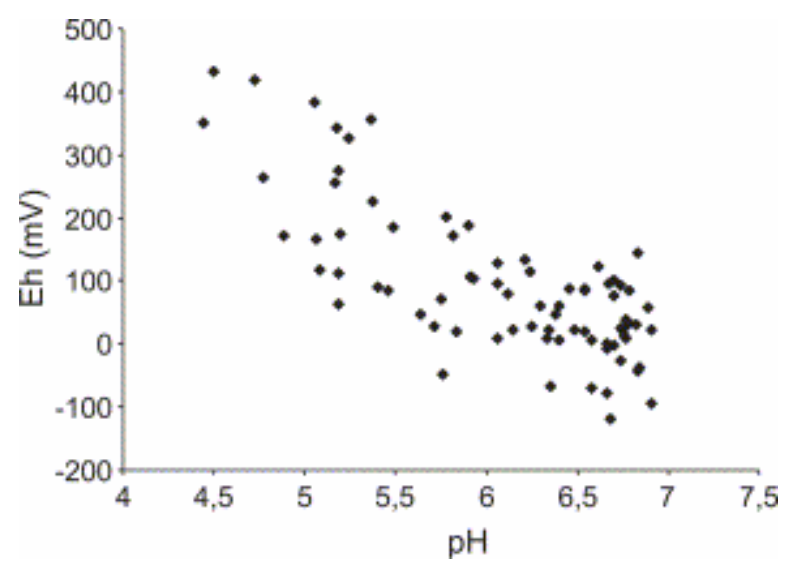

Fig. 9. Correlation between Eh and $\mathrm{pH}$ in sediments of the mature and senescent mangrove forests.

\subsection{Total sulphide concentration and total sulphur}

Sulphide concentrations in pore-water and total sulphur in sediment are represented on the same graphic (Fig. 10). Total sulphur and sulphide concentrations displayed the same distribution pattern in most mangrove substrates. Their concentration varied with stages of forest development, depth and plant species. Concerning the pioneer to young mature Avicennia mangrove, total sulphur values were very low and sulphide concentrations were below detection. In contrast beneath young Rhizophora stands (C25), a 
peak in total sulphur reached $1.3 \%$ at $55 \mathrm{~cm}$ deep (Fig. 10e). In the older Rhizophora forest (C28), total sulphur values were close to $4 \%$ and sulphide concentration reached $5 \times 10^{-5} \mathrm{M}$ (Fig. 10f). At the end of the rainy season, in the senescent mangrove (C12), sulphide concentrations reached $3 \times 10^{-6} \mathrm{M}$ at $30 \mathrm{~cm}$ deep, then sharply decreased (Fig. 10 C). Total sulphur was maximum, close to $0.9 \%$ at $35 \mathrm{~cm}$ depth. In sediments from the A. geminans mature forest (C20) performed in January 2002, sulphide was not detectable in the uppermost $25 \mathrm{~cm}$, increased sharply to $2 \times 10^{-5} \mathrm{M}$ between 30 and $40 \mathrm{~cm}$, then decreased steadily to below detection at depth (Fig. 10b). High sulphur contents $(1.5 \%)$ were also found in sediments of the dead recolonized mangrove (C2) in spite of the absence of dissolved sulphide (Fig. 10d). Sulphide was undetectable in layers characterized by high Eh values.
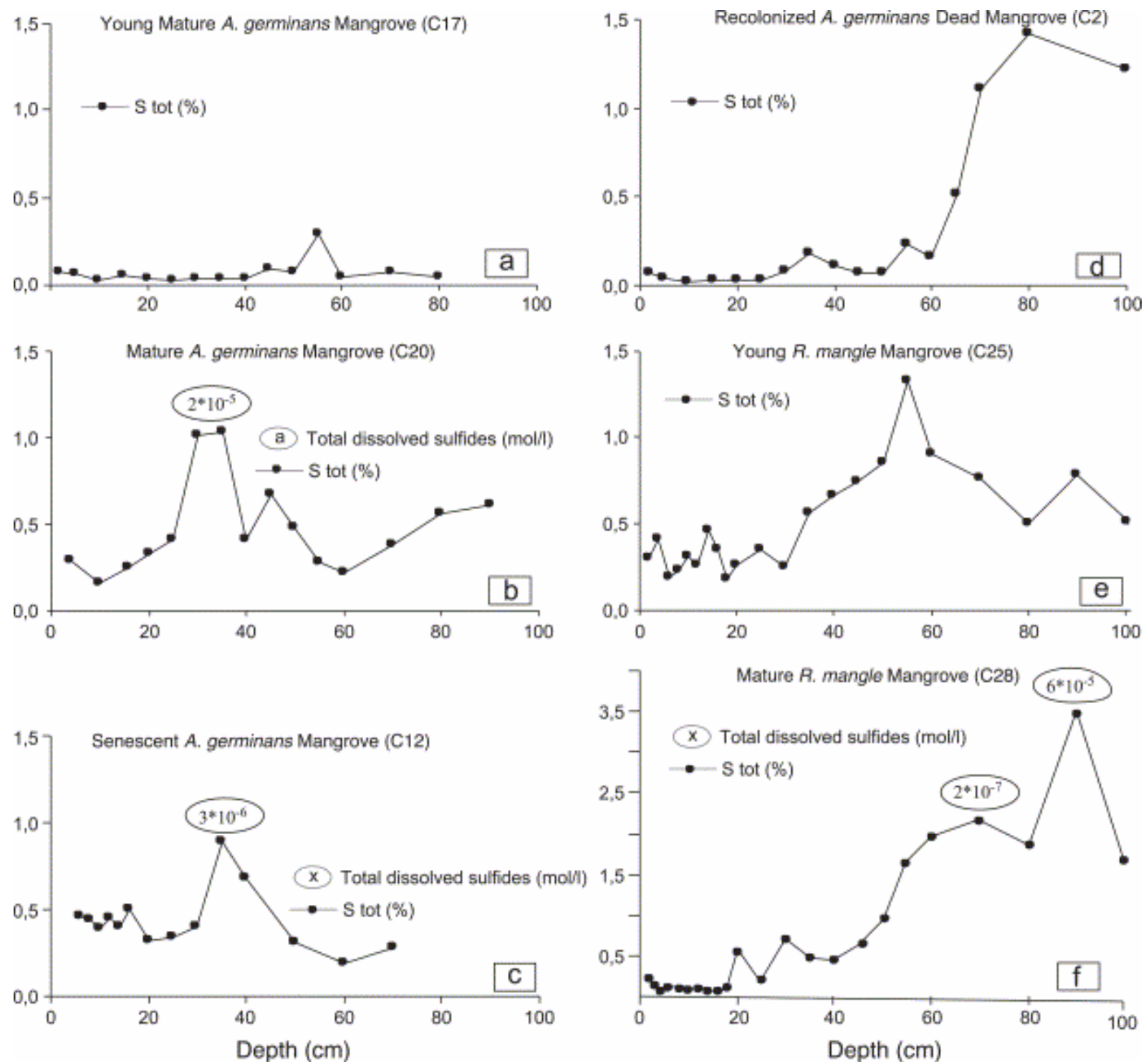

Fig. 10. Depth distribution of total sulphur in sediment, measured with LECO analyser and total dissolved sulphide concentration, derived from electrode potential measured by directly inserting probes into the sediment (electrodes was calibrated with solutions of $\mathrm{Na}_{2} \mathrm{~S}$ ). (a) Young A. geminans mangrove forest, July 2001, (b) mature A. geminans mangrove forest, Sinnamary, January 2002, (c) senescent A. geminans mangrove forest, Sinnamary, July 2001, 
(d) recolonized cemetery A. gemminans mangrove forest, July 2001, (e) R. mangle forest, Kaw, January 2002, (f) Mature R. mangle forest, Kaw January 2002.

\section{Disc ussion}

The complex geochemistry of mangrove sediments is a result of a large number of interacting physical and biological factors controlling sedimentary processes. These include properties of the shoreface sediment on which mangroves develop, the physiographical characteristics of the area, the influences of climate and the modification by vegetation. The coastline of the Guianas has four essential physical characteristics critical to mangroves. First, probably comes the highly dynamic character of this shoreline as evidenced by the rapidly migrating mudbanks (1.4 km/year, Allison et al., 2000). Dynamic actions result here in an accretion/erosion process that provides the mangroves with a limited span of life. Secondly, in spite of its fine grain size, the sediment of Amazonian origin is suboxic (Fig. 7a), because it is constantly remobilized by waves and currents (Aller, 1998). The third point is the shifting of the InterTropical Convergence Zone that induces strong seasonal variations in rainfall and evaporation. Finally, various rivers indent the coastline. According to its widespread occurrence, A. geminans seems to be the mangrove species best adapted to this very specific context.

The salt tolerance of Avicennia has been frequently demonstrated in North America (McMillan, 1975), in the Persian Gulf (Kendall and Skipwith, 1969), in Nigeria (Ukpong, 1997) and in Pakistan (Khan and Aziz, 2001). In the area studied, our results show that Avic ennia can tolerate a wide range of salinities, with values ranging from 5 to 55 at the sediment surface (Fig. 3 ). Although, our field observations reveal that $\mathrm{R}$. mangle grows in areas that are occasionally flooded with fresh water, adjacent to rivers or to freshwater swamps (Pterocarpus). On the other hand, the depth distributions of salinities beneath Avicennia and Rhizophora stands are generally similar. This may suggest that, in French Guiana, Rhizophora require or withstand occasional fresh water inundation but that salinity can not be considered as the primary determinant of species zonation in this region.

All sites showed different salinity between upper sediment and the basal layer for which salinity was either greater or the same (dry season, Fig. 4a). Surface salinities strongly varied, ranging from 2 to 50 , responding to physical factors (evaporation, intensity of rain, tidal flooding and position in the mangrove) and biological factors (transpiration). During dry seasons, surface salinity is five times that of the wet seasons (Fig. 4a), and twice that of seawater highlighting the influence of evaporation, as observed in Australia by Sam and Ridd (1998). The intensity and the duration of rain is the second external factor controlling surface salinity; early in the rainy season salinity values stabilized at $25 \mathrm{~cm}$ depth, whereas values stabilized at $60 \mathrm{~cm}$ depth at the end. Finally, the lowest salinity values were found in the interior mangrove, 
which were submitted to fresh water discharge, highlighting the importance of this position in the swamp, i.e., the proximity of minor river outlets and underground percolation. Combined with evaporation, plant transpiration is a biological factor that may increase pore-water salinity. Transpiration was not quantified in this study; nevertheless, the fact that salinities measured beneath a recolonized dead forest (C2) were twice as high as those below the adjacent dead forest (C4) (Fig. 3a) suggests the influence of this biological factor in raising salinity. Moreover, salinity increased with plant development, i.e., from the pioneer $(\mathrm{Cl1})$ to the young mature forest $(\mathrm{Cl}, \mathrm{C} 17)$ (Fig. 3). These results highlight the strong feedback effect exerted by the plants over the sediment. A. geminans produce horizontal cable roots that radiate several meters through the substrate just below the sediment surface (in the upper $30 \mathrm{~cm}$ ); upright pneumatophores and thin anchor roots are produced by the horizontal system (Fig. 11) (de Granville, 1974). Consequently, we suggest that transpiration mostly occurs in the upper sediment and cannot explain the surprisingly high and stable basal salinities.

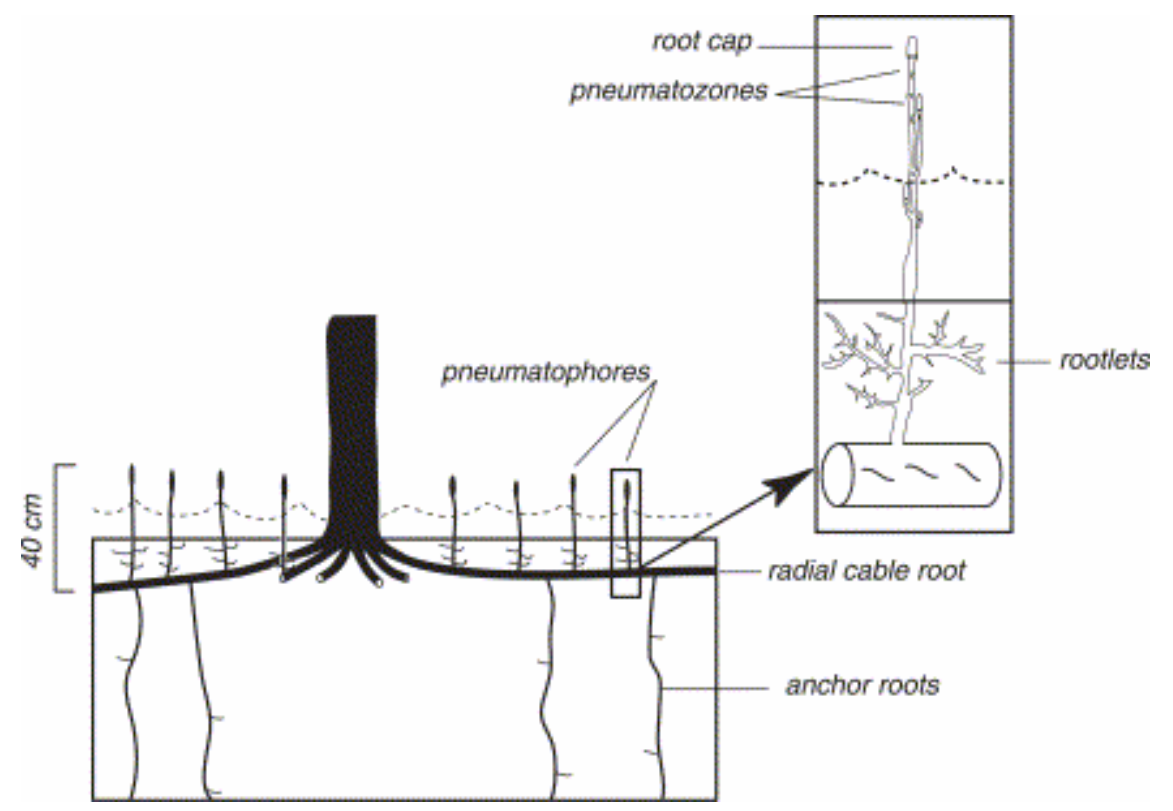

Fig. 11. A. geminans radial cable root system (adapted from de Granville, 1974).

The flow of underground water may play a key role in salinity distribution in mangrove swamps of French Guiana, as suggested by the time course of salinities with depth which implies some advection of salt water beneath fresh or less saline water, as demonstrated in other mangroves (Baltzer, 1982; Baltzer et al., 1994 and Thibodeau et al., 1998). Mangroves of French Guiana are mostly characterized by a fine-grained substrate, and the permeable sandy layers that might conduct high salinity waters laterally are limited to a number of scattered cheniers. As a consequence, considering that evapotranspiration mostly occurs in the upper layer and that the average permeability of the substrate is low, we suggest that the highly saline porewaters found in the deeper muds result from vertical migration of water. This 
process may occur through crab holes, as demonstrated by Ridd (1996), or by holes created by anchor roots. However, none of these conduits reach a depth of $1 \mathrm{~m}$. In addition, such processes should result in basal concentrations close to the average surface values rather than the maximum surface values. Therefore, we suggest that salts migrate downwards through convection processes. Due to the low soil permeability, this process must be very slow, and it results in the cumulation of the highest salinities over possibly many years. Convection will occur as the gravitational adjustment to the occurrence of surface pore-water, which presents higher salinity and density than the water below it (Webster et al., 1996 and de Vos et al., 2002). This process may also explain the constrained range of salinities at depth. Convection probably occurs mostly around the end of the dry season, when evapo-transpiration is at a maximum. Considering that evapo-transpiration leads to maximum salinities close to 50 in the upper layer, the maximum salinities at depth should be in the same range, which is the case.

The ability of $A$. germinans to oxidize the sediment thanks to its roots has been described by Scholander et al. (1955), whereas Hesse (1961a) observed that Rhizo phora bearing soils were sulphidic. Subsequently, sulphide concentration has been described as a key factor in vegetation distribution (Nickerson and Thibodeau, 1985; McKee et al., 1988; McKee, 1993 and Youssef and Saenger, 1999). McKee et al. (1988) observed low sulphide concentrations and high Eh values in soils adjacent to mangrove roots. They established a negative correlation between pneumatophore density and sulphide concentration. In 1993. McKee concluded that plant species distribution was correlated with soil redox potential and sulphide concentration, mentioning the reciprocal effect between soil characteristics and tree roots. Thibodeau and Nickerson (1986) observed large oxidized rhizospheres created by Avicennia's roots. In French Guiana, various redox processes may occur beneath Avicennia stands. The high Eh values found in the younger mangroves of French Guiana (Fig. $7 b, c)$, regardless of season, are consistent with these previous observations. Additionally, Eh values increased with forest age, from the pioneer to the young mature forest, suggesting an increase in oxygen release from roots correlated with the growth of trees, highlighting the influence of the rhizosphere on sediment geochemistry. Moreover, these forests are flooded at each tide, permitting a renewal of oxidizing elements. In such mangroves, there were neither sulphide nor sulphur in the sediment, highlighting suboxic processes in the upper $40 \mathrm{~cm}$, whereas the basal sediment had the same characteristics as the shoreface sediment.

Regarding the older forests, i.e., mature, mixed and senescent mangroves, Eh depth profiles were clearly different in the upper sediment, whereas the basal layer had the same characteristics (Fig. 7d,e). The oxidized zone at the rhizosphere level no longer exists. The fact that these forests are not tidally enriched in oxidizing elements may contribute to this trend. However, the main hypothesis is that as the forest develops, the input in fresh organic matter is stronger, moreover, the tidal export is impaired by distance from free 
sea water and by relief of the swamp surface (it is higher in mature than in pioneer and in senescent Avicennia swamps) (Table 2) (Marchand et al., 2003). This increased amount of fresh organic matter leads to sulphate reduction processes with production of framboids of pyrite previously observed in optical study (Marchand et al., 2003). In that case, one of two alternative situations prevails depending on the extent of waterlogging. Under the influence of wet seasons, the water table is high and the decay process leads to sulphate reduction. As a consequence, higher sulphur content (Fig. 10c) and low Eh values are recorded in the whole depth profile. In contrast, during the dry season, the water table is lower and the diffusion of oxygen in the unsaturated sediment adds its effect to that of the rhizosphere, allowing for the suboxic decay of organic matter and sulphur oxidation. This results in a relatively dry upper layer displaying low sulphur concentrations, high Ehs and low pHs overlying a lower, waterlogged layer, which is still subject to sulphate reducing processes. With the next rainy season, a new sulphate reducing system gradually replaces the suboxic level from the top downward. A temporary three-layered diagenetic system takes place until the intermediate, suboxic layer is totally reduced (ig. 7e).

Beneath Rhizophora stands, no effect on the oxidation state of the surrounding sediment was recorded. Eh values were low in the whole depth profile at all seasons (Fig. 7f). Organic decay seems to be dominated by sulphate-reducing processes as demonstrated by Lallier-Vergès et al. (1998) and Alongi et al. (2000), inducing high sulphide concentrations (Fig. 10e,f). Whatever the species, sulphide-rich layers are correlated with the low Eh values.

In 2000, Alongi et al. also observed a fundamental difference between Avic ennia and Rhizophora. They demonstrated that $\mathrm{O}_{2}$ respiration accounted for nearly $80 \%$ of the total oxidation of carbon in the soil of a young Avic ennia forest with a TOC of 1.7. This percentage fell to $45 \%$ and the organic content increased fourfold in places where the forest formed a denser shelter. This observation is in perfect agreement with our analyses, highlighting the role of reactive organic content. The authors also observed that the rates of sulphate reduction were greater in Rhizophora than in Avicennia forests. Clark et al. (1998) presented a model of redox stratification in an Avic ennia-dominated mangrove forest, describing the importance of the Avicennia radial cable roots in the oxidation of sediment, and the influence of the seasonal oscillations of the water table. In many studies, the concentration of sulphide is rather considered as a consequence than a cause for the zonation of plant species.

The $\mathrm{pH}$ varied considerably with depth and season in the mangroves of French Guiana. Two different patterns of $\mathrm{pH}$ distributions were recognizable in the upper sediment, as a function of organic matter decomposition and of sulphur oxidation. In contrast, the $\mathrm{pH}$ values of basal sediment, displayed only one monotonous distribution type centered around 6.7, and remarkably 
similar to that of shoreface sediment. From the pioneer to the young mature A. geminans mangroves, which were both tidally flooded and characterized by a low organic accumulation, the fall in $\mathrm{pH}$ values, to 6.1, at the level of radial cable roots (Fig. 5b), correlated with the increase in redox values, is probably derived from the decay of organic matter. Whatever depth or season, neither sulphur nor sulphide were found at these stages, suggesting that this decrease cannot be derived from sulphur oxidation. However, only a very small quantity of solid $\mathrm{S}$ needs to be oxidized to lower the $\mathrm{pH}$, and it may well be impossible to detect any residual. In any case, a lack of $S$ oxidation or its occurrence could be checked by examining the $S$ isotopic composition of the pore-water $\mathrm{SO}_{4}$. Conversely, in the upper sediment, the tidal supply of basic cations contributes to an increase in $\mathrm{pH}$. Ovalle et al. (1990), observed an increase in salinity, dissolved oxygen and $\mathrm{pH}$, at flood tides, whereas this pattern was reversed at ebb tides. In the depth profiles presented herein, $\mathrm{pH}$ values could be slightly lowered in the uppermost $4 \mathrm{~cm}$ because cores were collected during low tide. Concerning mature and senescent A. geminans mangroves, which were flooded only at spring tide, submitted to fresh water discharge and characterized by a high organic accumulation, the really acidic values, inversely correlated with the redox values, seem to be derived from both organic matter decay and sulphur oxidation. During the rainy season, the whole depth profile is submitted to sulphate-reducing processes, and framboids of pyrite can form; whereas during the dry season, suboxic processes can develop in the upper sediment overlying the zone of sulphate reduction. Consequently, during dry season, oxidation of both pyrite and dissolved sulphide occur in the upper sediment, as shown by the negative correlation between $\mathrm{pH}$ and Eh (Fig. 9), and as observed in other mangroves (Hesse, 1961b and Aragon et al., 1999). This process and the organic matter decomposition in suboxic conditions strongly acidify the upper sediment.

Accordingly, in the present study, high sulphur content was found both under R. mangle and A. geminans mainly depending on the decomposition of organic matter, while the unvegetated shoreface sediment did not contain any sulphide or sulphur. The increase in sulphur content may also come from the stabilization of deposits by plant communities. This increase may be related to the overall decrease in reoxidation frequency by the physical remobilization of deposits occurring along the coastline of the Guianas. Nevertheless, sedimentary sulphur and dissolved sulphide were only observed in the zone of introduction of fresh organic matter (zone of root development) and not below. In depth, even in the older mangrove, stabilization of deposits does not seem to have an influence on the diagenetic regime and on the presence of sulphur. Redox values were below $100 \mathrm{mV}, \mathrm{pH}$ was close to 6.7 and no sulphur was present: These characteristics are similar to those of the shoreface sediment. This confirms the influence of plant development on the chemical evolution of the substrate. However, our results cannot indicate to what extent these plant species might directly colonize a sulphide-rich sediment because of the lack of sulphide in the original mud bank. 
Previous studies have highlighted the difficulties in determining the origin of mangrove zonation. Matthijs et al. (1999) observed that the distribution of Avic ennia marina could not be correlated with the distribution of Eh values, sulphide concentration nor salinity. In contrast, they observed high sulphide contents linked with low Eh values beneath Rhizophora mucronata. They mentioned that this species, developing close to a creek, was probably more frequently submitted to fresh water flow and to higher levels of water table than Avic ennia under which there was no sulphide and higher Eh values. This is in agreement with our observations on the implantation of Rhizophora and with our results on sulphide distribution. No conclusive mechanism was proposed for this zonation. In French Guiana, we suggest that the shape of propagules could be the predominant factor controlling the recruitment of mangroves along this dynamic coastline. The small bean-like seedlings of Avic ennia would be able to resist wave action after easily taking root into the sediment (Osborne and Berjak, 1997), while the much larger, elongated propagules of Rhizophora would be easily washed away. Moreover, Terrados et al. (1997) suggested, in an experimental study, that Rhizophora a picula ta seedlings could not colonize coastal areas submitted to sudden sediment accretion $(>4 \mathrm{~cm})$ : The coastline of the Guianas presents those kinds of highly dynamic features. Additionally, McKee (1995) observed that R. mangle mortality is influenced by the initial orientations of the axes of the sedimented seedlings, such that mortality is higher when the propagules take root in an horizontal position, as they do in Guiana as a consequence of currents and tidal ranges.

\section{Conclusion}

Several conclusions regarding reciprocal interactions between vegetation and substrate in the Guiana coastal environment can be derived from our study. They are summarized in a schematic diagram (Fig. 12) describing the evolution of the physico-chemical parameters in the A. geminans forest, with respect to season and forest development. Concerning salinity, data previously presented in the literature and in this study highlight a wide range of tolerance to salinity for A. geminans (frequently cultivated under freshwater conditions). Two different systems should be distinguished: (i) salinities of the upper sediment vary regularly during the year, with tides, rain or proximity to a river sources, factors that tend to lower salinity, and with evapo-transpiration that tend to increase salinity; (ii) in the basal layer, salts accumulate probably due to convection processes occurring during the dry season, resulting in high and stable salt concentration. No clear differences were found between A. geminans and R. mangle in this regard. In contrast, a significant difference between the two species was shown by the depth distribution of redox conditions. Remarkably high values occur under young Avicennia stands, highlighting the ability of Avicennia to oxidize the upper sediment with its radial cable roots. Net oxidation takes place where the organic content is low. Accordingly, beneath the younger A. geminans mangrove forests, the hypothesis is that the amount of oxygen released by 
roots is sufficient to largely degrade the low organic content which is present, slightly acidifying the sediment. As a consequence, sulphide concentrations remain as low as in uncolonized shoreface sediment. In the older stages of Avic ennia mangrove forests, the oxygen released by roots is insufficient to decompose the large quantity of organic matter which has progressively accumulated. Low Eh values associated with the high sulphur concentrations in these deposits denote sulphate-reducing processes similar to those also observed under Rhizophora stands. Vertical oscillations of the water table produced by climatic influences modify redox and decomposition processes. During dry seasons, the water table is lowered and diffusion of oxygen in the sediment adds its effect to those of the rhizosphere inducing a stratification of the redox processes, i.e., a layer of sulphur oxidation, characterized by highly acidic values, overlying a layer of sulphate reduction. Animal bioturbation may cause similar effects but to a lesser extent. These results demonstrate that the sulphur content depends on the organic matter decomposition and reoxidation, which in turn depend on both the plant species, the amount of freshly introduced organic matter, and gas/pore-water transport. This study suggests that, in contrast with many regions, neither salinity nor sulphur (or dissolved sulphide) concentration are major factors responsible for the distribution of Avic ennia and Rhizophora in the mangroves of French Guiana. The predominant development of Avic ennia is probably due to the ability of its seedlings to take root into frequently reworked sediment. These results also demonstrate that the characteristics of the pore-water are highly interlinked and depend to a large extent on the environmental conditions. In turn, they interact with the mineral phase as exemplified by the early diagenetic effects resulting in the formation of Fe sulphides (this paper and Andrade et al., this volume). These solid sulphides along with other neoformed minerals and organic matter are eventually eroded, put in suspension and reincorporated, into some downstream element of the mobile belt of mud banks which constitute the coast of the Guianas. 
Pioneer to young mature A. germinans mangrove forest,

low organic carbon, flooded at each tide.

\section{Eh (mV)}

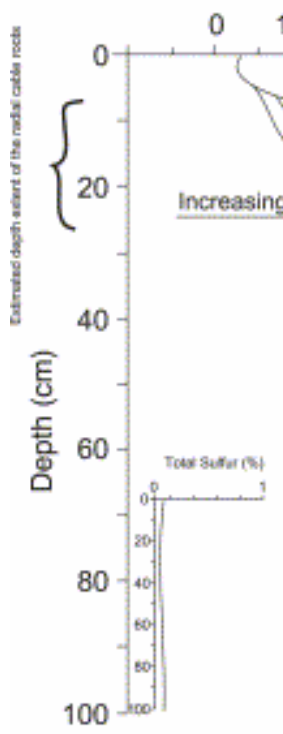

400

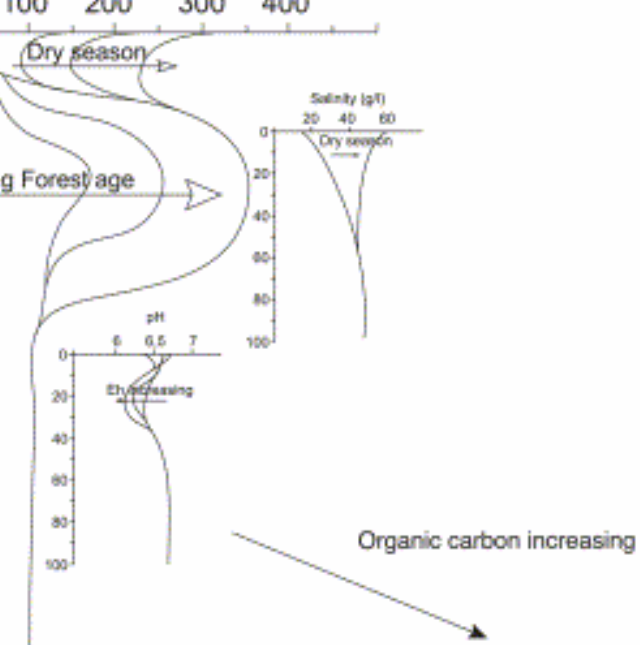

Mature and senescent $A$. germinans mangrove torest, organic rich, flooded at spring tide.

$$
\text { Eh }(\mathrm{mV})
$$

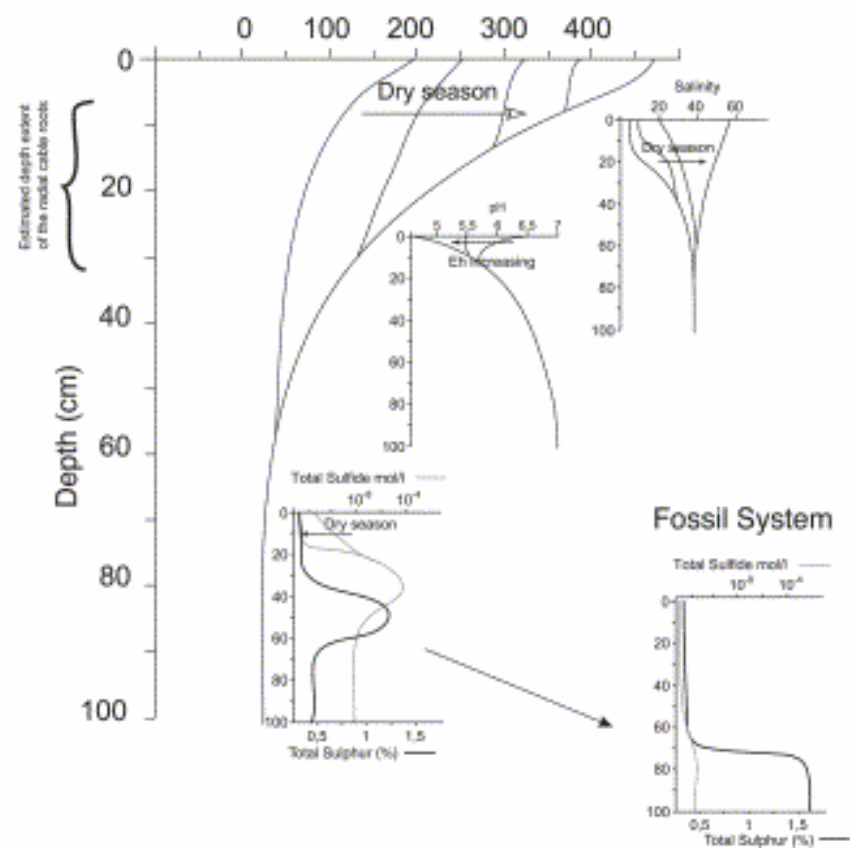

Fig. 12. Schematic diagram of physico-chemical parameters evolution in an A. germinans forest with respect to season and organic content.

\section{Acknowledgements}

This research was supported by INSU and the PNEC Guyane. The authors would like to thank IRD Cayenne and F. Fromard (Univ. P. Sabatier, Toulouse, France) for their valuable assistance on field. The help of R.C. Aller, I.A Mendelssohn, and G. Sarazin for the improvement of this manuscript is gratefully acknowledged. 


\section{References}

Albéric, P., 1976. Les gaz dissous dans les eaux interstitielles des sédiments en rapport avec les phénomènes d'oxydo-réduction. PhD thesis, Université Paris VII, $58 \mathrm{pp}$.

Aller, R.C., 1998. Mobile deltaic and continental shelf muds as suboxic, fluidized bed reactors. Mar. Chem. 61, pp. 143-155

Allison, M.A., Lee, M.T., Ogston, A.S. and Aller, R.C., 2000. Origin of Amazon mudbanks along the northeastern coast of South America. Mar. Geol. 163, pp. 241-256.

Alongi, D.M., Sasakumar, A., Tirendi, F. and Dixon, P., 1998. The influence of stand age on benthic decomposition and recycling of organic matter in managed mangrove forests of Malaysia. J. Exp. Mar. Biol. Ecol. 225, pp. 197218.

Alongi, D.M., Tirendi, F., Trott, L.A. and Brunskill, G.J., 1999. Mineralisation of organic matter in intertidal sediments of a tropical semi-enclosed delta. Estuar., Coast. Shelf Sci. 48, pp. 451-467.

Alongi, D.M, Tirendi, F. and Clough, B.F., 2000. Below-ground decomposition of organic matter in forests of the mangrove Rhizophora stylosa and Avic ennia marina along the arid coast of Western Australia. Aquat. Bot. 68, pp. 97-122.

Aragon, G.T., Ovalle, A.R.C. and Carmouze, J.-P., 1999. Porewater dynamics and the formation of iron sulphides in a mangrove ecosystem, Sepetiba Bay, Brazil. Mangroves Salt Marshes 3, pp. 85-93.

Baltzer, F., 1969. Les formations végétales associés au delta de la Dumbea (Nouvelles Calédonies) et leurs indications écologiques, géomorphologiques et sédimentologiques mises en évidence par la cartographie. Cah. ORSTOM, Ser. Géol. I, I, pp. 59-84.

Baltzer, F., 1975. Solution of silica and formation of quartz and smectite in mangrove swamps and adjacent hypersaline marsh environments. Proceedings of the Intemational Symposium on Biology and Management of Mangroves, Univ. Florida, pp. 482-498.

Baltzer, F., 1982. La transition eau douce-eau salée dans les mangroves. Conséquences sédimentologiques et géochimiques. Mém. Soc. Géol. Fr. 144, pp. 27-42.

Baltzer, F., Kenig, F., Boichard, R., Plaziat, J.C. and Purser, B.H., 1994. Organic matter distribution, water circulation and dolomitization beneath the Abu Dhabi sabka (UAE). In: Purser, B.H., Tucker, M.E. and Zenger, D.H., Editors, 1994. 
Special Publication of the Intemational Association of Sedimentologists vol. 21, pp. 409-427.

Blasco, F., Saenger, P. and Janodet, E., 1996. Mangroves as indicators of coastal change. Catena 27, pp. 167-178.

Boulègue, J., 1974. Etude expérimentale du comportement du soufre dans les milieux marins oxydants et réducteurs. Conséquences pour la matière organique. In: Advances in Organic Geochemistry, 6th IMOG 1973, Editions Technip, Paris, pp. 813-827.

Boulègue, J. and Michard, G., 1973. Formation de polysulfures dans les conditions physico-chimiques de l'eau de mer. C. R. Acad. Sci. Paris, Sér. D 277, pp. 2613-2616.

Chapman, V.J., 1976. Coastal Vegetation. , Pergamon, Oxford.

Clark, M.W., McConchie, D., Lewis, D.W. and Saenger, P., 1998. Redox stratification and heavy metal partitioning in Avic ennia-dominated mangrove sediments: a geochemical model. Chem. Geol. 149, pp. 147-171.

de Granville, J.J., 1974. Aperçu sur la structure des pneumatophores de deux espèces des sols hydromorphes en Guyane. Cah. ORSTOM, Sér. BD 23, pp. 322.

de Vos, J.A., Raats, P.A.C. and Fedes, R.A., 2002. Chloride transport in a recently reclaimed Dutch polder. J. Hydrol. 257, pp. 59-77.

Egler, F.E., 1948. The dispersal and establishment of the mangrove, Rhizo phora, in Florida. Caribb. For. 9, pp. 299-310.

Fromard, F., Puig, H., Mougin, E., Marty, G., Betoulle, J.L. and Cadamuro, L., 1998. Structure, above ground biomass and dynamics of mangrove ecosystems: new data from French Guiana. Oecologia 115, pp. 39-53.

Garrels, R.M. and Christ, C.L., 1965. Solution, Minerals and Equilibria. , Harper \& Row, New York 450 pp. .

Green, E.J. and Schnitker, D., 1974. Direct titration of total soluble sulphide in estuarine muds of Montsweag bay, Maine. Mar. Chem. 2, pp. 111-124. Abstract

Hesse, P.R., 1961. The decomposition of organic mater in a mangrove swamp soil. Plant Soil 14, pp. 249-263.

Hesse, P.R., 1961. Some differences between the soils of Rhizophora and Avic ennia mangrove swamp in Sierra Leone. Plant Soil 14, pp. 335-346. 
Kendall, C.G.St.C. and Skipwith, P.A.d.E., 1969. Geomorphology of a recent shallow-water carbonate province: Khor al Bazam, Trucial Coast, South West Persian Gulf. Geol. Soc. Amer. Bull. 80, pp. 865-892.

Khan, A.M. and Aziz, I., 2001. Salinity tolerance in some mangrove species from Pakistan. Wetlands Ecol. Mana g. 9, pp. 219-223.

Lacerda, L.D., Ittekkot, V. and Patchineelam, S.R., 1995. Biogeochemistry of mangrove soil organic matter: a comparison between Rhizo phora, Avic ennia soils in south-eastern Brazil. Estua r., Coast. Shelf Sci. 40, pp. 713-720.

Lallier-Vergès, E., Perrussel, B., Disnar, J.R. and Baltzer, F., 1998. Relationships between environmental conditions and the diagenetic evolution of organic matter derived from higher plants in a modern mangrove swamp system (Guadeloupe French West Indies). Org. Geochem. 29, pp. 1663-1686.

McKee, K.L., 1993. Soil physicochemical patterns and mangrove species distribution-reciprocal effects? J. Ecol. 81, pp. 477-487.

McKee, K.L., 1995. Seedlings recruitment patterns in a Belizean mangrove forest: effects of establishment ability and physico-chemical factors. Oecologia 101, pp. 448-460.

McKee, K.L., Mendelssohn, I.A. and Hester, M.W., 1988. Reexamination of pore water sulphide concentrations and redox potentials near the aerial roots of Rhizo phora mangle and Avic ennia geminans. Am. J. Bot. 75, pp. 1352-1359.

McMillan, C., 1975. Interaction of soil texture with salinity tolerances of Avicennia geminans (L.) Lam. and Laguncularia racemosa (L.) Gaertn. f. from North America. In: Proceedings of the Intemational Symposium on Biology and Management Resource Management Systems Program, Univ. Florida, pp. 561-566.

Marchand, C., Lallier-Vergès, E. and Baltzer, F., 2003. The composition of sedimentary organic matter in relation to the dynamic features of a mangrove-fringed coast in French Guiana. Estuar., Coast. Shelf Sci. 56, pp. 119-130.

Matthijs, S., Tack, J., van Speybroeck, D. and Koedam, N., 1999. Mangrove species zonation and soil redox state, sulphide concentration and salinity in Gazi Bay (Kenya), a preliminary study. Mangroves Salt Marshes 3, pp. 243-249.

Naidoo, G., 1985. Effect of waterlogging and salinity on plant-water relations and on the accumulation of solutes in three mangrove species. Aquat. Bot. 22, pp. 133-143.

Nickerson, N.H. and Thibodeau, F.R., 1985. Association between pore water sulphide and distribution of mangroves. Biogeoc hemistry 1, pp. 183-192. 
Orion Research, 1970. Instruction Manual: Sulphide Ion Electrode. , Orion Research, Cambridge, Massuchetts 28 pp. .

Osborne, D.J. and Berjak, P., 1997. The making of mangroves: the remarkable pioneering role played by seeds of Avic ennia marina. Endeavour 21, pp. 143147.

Ovalle, A.R.C., Rezende, C.E., Lacerda, L.D. and Silva, C.A.R., 1990. Factors affecting the hydrochemistry of a mangrove tidal creek, Sepetiba Bay, Brazil. Estuar., Coast. Shelf Sci. 31, pp. 639-650.

Pezeshki, S.R., DeLaune, R.D. and Meeder, J.F., 1997. Carbon assimilation and biomass in Avicennia geminans and Rhizophora mangle seedlings in response to soil redox conditions. Environ. Exp. Bot. 37, pp. 161-171.

Rabinowitz, D., 1978. Dispersal properties of mangrove propagules. Biotropica 10, pp. 47-57.

Ridd, P.V., 1996. Flow through animal burrows in mangrove creeks. Estuar., Coast. Shelf Sci. 43, pp. 617-625.

Sam, R. and Ridd, P., 1998. Spatial variations of groundwater salinity in a mangrove salt-flat system, Cocoa Creek, Australia. Mangroves Salt Marshes 2 , pp. 121-132.

Scholander, P.F., Van dam, L. and Scholander, S.I., 1955. Gas exchange in the roots of mangrove. Am. J. Bot. 42, pp. 92-98.

Service Hydrographique et Océanographique de la Marine (SHOM), 2001. Annuaire des marées pour l'an 2002. Ports d'outre-mer. Editions du SHOM, Brest.

Smith, T.J., Chan, H.T., Mclvor, C.C. and Robblee, M.B., 1989. Comparison of seed predation in tropical tidal forests from three continents. Ecology 70, pp. $146-151$.

Snedaker, S.C., 1982. Mangrove species zonation: why?. In: Sen, D.N. and Rajpurohit, K.S., Editors, 1982. Contribution to the Ecology of Ha lophytes, Tasks for Vegetation ScienceW. J unk, The Hague vol. 2, pp. 111-126.

Terrados, J., Thampanya, U., Srichai, N., Kheowvongsri, P., Geertz-Hansen, O., Boromthanarath, S., Panapitukkul, N. and Duarte, C.M., 1997. The effect of increased sediment accretion on the survival and growth of Rhizophora a pic ula ta seedlings. Estua r., Coast. Shelf Sci. 45, pp. 697-701.

Thibodeau, F.R. and Nickerson, N.H., 1986. Differential oxidation of mangrove substrate by Avic ennia geminans and Rhizo phora mangle. Am. J. Bot. 73, pp. 512-516. 
Thibodeau, P.M., Gardner, L.R. and Reeves, H.W., 1998. The role of groundwater flow in controlling the spatial distribution of soil salinity and rooted macrophytes in a southeastern salt marshes, USA. Mangroves Salt Marshes 2, pp. 1-13

Ukpong, I.E., 1997. Vegetation and its relation to soil nutrient and salinity in the Calabar mangrove swamp, Nigeria. Mangroves Salt Marshes 1, pp. 21 1-218.

Vismann, B., 1996. Sulphide exposure experiments: the sulphide electrode and a set-up automatically controlling sulphide, oxygen and pH. J. Exp. Mar. Biol. Ecol. 204, pp. 131-140.

Walsh, G.E., 1974. Mangroves, a review. In: Reimold, R.J. and Queen, W.H., Editors, 1974. Ecology of Halophytes, Academic Press, pp. 51-174.

Webster, I.T., Norquay, S.J., Ross, F.C. and Wooding, R.A., 1996. Solute exchange by convection within estuarine sediments. Estuar., Coast. Shelf Sci. 42, pp. 171-183.

Youssef, T. and Saenger, P., 1999. Mangrove zonation in Mobbs Bay-Australia. Estuar., Coast. Shelf Sci. 49, pp. 43-50. 